\title{
Forecasting Financial Stress Indices in Korea: A Factor Model Approach
}

\author{
Hyeongwoo Kim*, Hyun Hak Kim**, Wen Shi***
}

The views expressed herein are those of the authors and do not necessarily reflect the official views of the Bank of Korea. When reporting or citing this paper, the authors' names should always be explicitly stated.

* Department of Economics, Auburn University, 0339 Haley Center, Auburn, AL 36849.

Tel: +1-334-844-2928. Fax: +1-334-844-4615. Email: gmmkim@gmail.com.

** Macroeconomic Team, Bank of Korea, Institute of Economic Research, 55 Namdaemuno, Jung-gu, Seoul, Korea 100-794. Tel: +82-2-759-5471. Fax: +82-2-759-5420. Email: khdouble@bok.or.kr.

*** Department of Economics, Auburn University, 0316 Haley Center, Auburn, AL 36849.

Tel: +1-334-844-2911. Fax: +1-334-844-4615. Email: wzs0003@auburn.edu. 


\section{Contents}

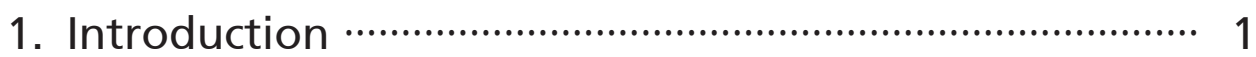

2. The Econometric Model …….................................. 3

3. Data Descriptions and Factor Estimations ….............. 7

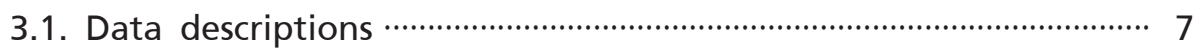

3.2. Latent factors and their characteristics ……............................... 9

4. Forecasting Exercises …….................................. 16

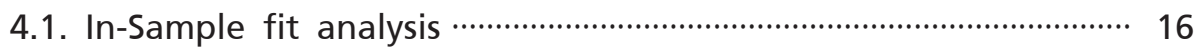

4.2. Out-of-Sample forecast exercises and model evaluations …….. 18

5. Concluding Remarks ……...................................... 25

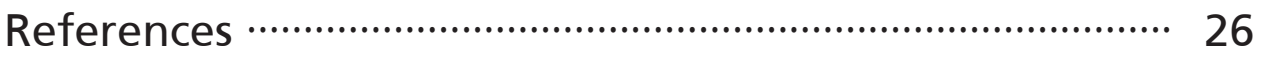




\section{Forecasting Financial Stress Indices in Korea: A Factor Model Approach}

We propose factor-based out-of-sample forecast models for the financial stress index and its 4 sub-indices developed by the Bank of Korea. We employ the method of the principal components for 198 monthly frequency macroeconomic data to extract multiple latent factors that summarize the common components of the entire data set. We evaluate the out-of-sample predictability of our models via the ratio of the root mean squared prediction errors and the Diebold-Mariano-West statistics. Our factor models overall outperform the random walk model in forecasting the financial stress indices for up to 1-year forecast horizon. Our models also perform fairly well relative to a stationary autoregressive model especially when the forecast horizon is short, which is practically useful because financial crises often occur abruptly with no systemic warning signals. Parsimonious models with small number of factors perform as well as bigger models. Overall, our findings imply that not only financial data but also real activity variables can help out-of-sample forecast the vulnerability in the financial markets.

Keywords: Financial stress index, Principal component analysis, PANIC, In-sample fit, Out-of-sample forecast, Diebold-Mariano-West Statistic

JEL Classification: C53, G17, C38 


\section{Introduction}

Financial market crises often occur abruptly and quickly spread to other sectors of the economies and even to other countries. For example, the bankruptcy of Lehman Brothers on September 15, 2008 resulted in the collapse of financial markets not only in the U.S. but also in other countries including Korea. These crises tend to come to a surprise realization with no systemic warnings. Since they create harmful long-lasting effects on real activities even after the financial system becomes stabilized, it would be useful to have an instrument, say an Early Warning Signal (EWS), which can provide timely information on the vulnerability in financial markets in the near future.

For this purpose, it is crucially important to find a measure of financial market vulnerability, which quantifies the potential risk that prevails in financial markets. One popularly used measure in the literature is the Exchange Market Pressure index (EMP). Since the work of Girton and Roper (1977), many researchers use this index to develop EWS mechanisms to detect money market turbulence across countries. See Tanner (2002) for a review.

One other measure that is rapidly gaining popularity is financial stress indices (FSTI)1). Unlike the EMP index that is based on exchange rate depreciation and reserves changes, the FSTI is constructed using a broad range of financial market key variables. There's an array of work that provides regional financial stress indices such as Grimaldi (2010), Grimaldi (2011), Hollo et al. (2012), and Islami and Kurz-Kim (2013) for the Euro area as well as for individual countries such as Greece (Louzis and Vouldis, 2011), Sweden (Sandahl et al., 2011), Canada (Illing and Liu, 2006), Denmark (Hansen, 2006), Switzerland (Hanschel and Monnin, 2005), Germany (Van Roye, 2011), Turkey(Cevik et al., 2013), Colombia (Morales and Estrada, 2010), and Hong Kong (S.Yiu et al., 2010). There are currently 12 FSTI type data available for the U.S. financial market (Oet et al., 2011) including four indices produced by the U.S. Federal Reserve system.

Conventional approaches to predict financial crises include the following. Frankel and Saravelos (2012), Eichengreen et al. (1995), and Sachs et al. (1996)

1) Bank of Korea produces financial stability indices as FSI so that financial stress indices are abbreviated to FSTI. 
use linear regressions to test the statistical significance of various economic variables on the occurrence of crises. Other group of researches employs discrete choice model approaches, either parametric probit or logit regressions (Frankel and Rose, 1996; Cipollini and Kapetanios, 2009) or nonparametric signals approach (Kaminsky et al., 1998; Brüggemann and Linne, 1999; Edison, 2003; Berg and Pattillo, 1999; Bussiere and Mulder, 1999; Berg et al., 2005; EI-Shagi et al., 2013; Christensen and Li, 2014).

Some of recent studies started to investigate what economic variables help predict financial market vulnerability proxied by newly developed FSTIs. For instance, Christensen and Li (2014) propose a model to forecast the FSTIs developed by IMF for 13 OECD countries, utilizing 12 economics leading indicators and three composite indicators. They used the signal extraction approach proposed by Kaminsky et al. (1998). Slingenberg and de Haan (2011) constructed their own FSTIs for 13 OECD countries and investigated what economic variables have predictive contents for the FSTIs via linear regression models, finding no clear linkages between economic variables and the FSTIs. Misina and Tkacz (2009) investigated the predictability of credit and asset price movements for financial market stress in Canada. Kim and Shi (2015) implemented forecasting exercises for the FSTI in the U.S. using a similar methodologies used in this paper.

The present paper seeks possible mechanisms to predict financial market vulnerability in Korea using a broad range time series macroeconomic data. We propose factor-based prediction models to out-of-sample forecast the financial stress index and its four sub-indices for the bond market, the foreign exchange market, the stock market, and the financial industry in Korea. Instead of using individual data series, we employ the method of the principal components (Stock and Watson, 2002) to extract multiple common factors from 198 monthly frequency time series data from October 2000 to December 2013. We categorized these 198 variables into 13 groups that include an array of nominal and real activity variables. We evaluate the out-of-sample forecast predictability of our models in comparison with two benchmark models, the nonstationary random 
walk (RW) and a stationary autoregressive (AR) models, via the ratio of the root mean square prediction errors (RRMSPE) and the Diebold-Mariano-West (DMW) test statistics.

Our major findings are as follows. First, our factor models overall outperform the RW model for most FSTI. Our models also perform reasonably well over the AR model especially for cases with short forecast horizons. Our model performed the best for the foreign exchange market over the RW model. That is, RRMSPE was substantially greater than one (smaller mean squared prediction errors of our models) and the $D M W$ test rejects the null of equal predictability for majority cases of the forecast horizons from 1 month to 1 year. Second, parsimonious models with just one single factor perform as well as bigger models that include up to 8 common factors. Especially, the first common factor that represent both the nominal and real activity variables seems to be sufficient to beat the RW model. Third, the fixed rolling window scheme tends to perform similarly well as the recursive approach when we choose the $70 \%$ split point. Overall, our findings imply that not only financial data but also real activity macroeconomic data help out-of-sample forecast the vulnerability in the financial markets.

The rest of the paper is organized as follows. Section 2 describes the econometric model and the out-of-sample forecasts schemes as well as the evaluation methods we employ in the present paper. In Section 3, we provide data descriptions and preliminary analyses for latent common factor estimates. Section 4 reports our major findings from in-sample fit analyses and out-of-sample forecast exercises. Section 5 concludes.

\section{The Econometric Model}

Let $x_{i, t}$ be a macroeconomic variable $i \in\{1,2, \cdots, N\}$ at time $t \in\{1,2, \cdots, T\}$.

$$
x_{i, t}=c_{i}+\lambda_{i}^{\prime} \mathbf{F}_{t}+e_{i, t},
$$

where $c_{i}$ is a fixed effect intercept, $\mathbf{F}_{t}=\left[F_{1, t} \cdots F_{r, t}\right]^{\prime}$ is an $r \times 1$ vector of latent common factors, and $\lambda_{i}=\left[\lambda_{i, 1} \cdots \lambda_{i, r}\right]^{\prime}$ denotes an $r \times 1$ vector of factor loading 
coefficients for $x_{i, t} \cdot e_{i, t}$ is the idiosyncratic error term. All variables other than those in percent (interest rates, unemployment rates, etc.) are log-transformed.

Estimation is carried out via the method of the principal components for the first-differenced data. As Bai and $\mathrm{Ng}$ (2004) show, the principal component analysis estimators for $\mathbf{F}_{t}$ and $\lambda_{i}$ are consistent irrespective of the order of $\mathbf{F}_{t}$ as long as $e_{i, t}$ is stationary. However, if $e_{i, t}$ is an integrated process, a regression of $x_{i, t}$ on $\mathbf{F}_{t}$ is spurious. To avoid this problem, we apply the method of the principal components to the first-differenced data. That is, we rewrite (1) by the following.

$$
\Delta x_{i, t}=\lambda_{i}^{\prime} \Delta \mathbf{F}_{t}+\Delta e_{i, t}
$$

for $t=2, \cdots, T$. Let $\Delta \mathrm{x}_{i}=\left[\Delta x_{i, 1} \cdots \Delta x_{i, T}\right]^{\prime}$ and $\Delta \mathrm{x}=\left[\Delta \mathrm{x}_{1} \cdots \Delta \mathrm{x}_{N}\right]$. We first normalize the data before the estimations, since the method of the principal components is not scale invariant. Taking the principal components method for $\Delta \mathrm{x} \Delta \mathrm{x}^{\prime}$ yields factor estimates $\Delta \hat{\mathrm{F}}_{t}$ along with their associated factor loading coefficients $\hat{\lambda_{i}}$. Estimates for the idiosyncratic components are naturally given by the residuals $\Delta \hat{e}_{i, t}=\Delta x_{i, t}-\hat{\lambda}_{x}^{\prime} \Delta \hat{\mathbf{F}}_{t}$. Level variables are then recovered by re-integrating these estimates,

$$
\hat{e}_{i, t}=\sum_{s=2}^{t} \Delta \hat{e}_{i, s}
$$

for $i=1,2, \cdots, N$. Similarly,

$$
\hat{\mathbf{F}}_{t}=\sum_{s=2}^{t} \Delta \hat{\mathbf{F}}_{s}
$$

After obtaining latent factor estimates, we employ the following regression model. Abstracting from deterministic terms,

$$
f s i_{t+j}=\beta_{j}^{\prime} \Delta \hat{\mathbf{F}}_{t}+\alpha_{j} f s i_{t}+u_{t+j}, j=1,2, \cdots, k
$$

That is, we implement direct forecasting regressions for the j-period ahead financial stress index $\left(f s i_{t+j}\right)$ on (differenced) common factor estimates $\left(\Delta \hat{\mathbf{F}}_{t}\right)$ and the 
current value of the index $\left(f s i_{t}\right)$, which belong to the information set $\left(\Omega_{t}\right)$ at time t. Note that (5) is an AR (1) process for $j=1$, extended by exogenous common factors $\Delta \hat{\mathbf{F}}_{t}$ This formulation is based on our preliminary unit-root test results for the FSTIs that show strong evidence of stationarity.2) Applying the ordinary least squares (OLS) estimation for (5) yields the following $j$-period ahead forecast for the financial stress index.

$$
\widehat{f s i}_{t+j \mid t}^{F}=\widehat{\beta}_{j}^{\prime} \Delta \hat{\mathbf{F}}+\hat{\alpha}_{j} f s i_{t}
$$

To statistically evaluate our factor models, we employ the following nonstationary random walk (RW) model as a (no change) benchmark model.

$$
f s i_{t+1}=f s i_{t}+\varepsilon_{t+1}
$$

It is straightforward to show that (7) yields the following $j$-period ahead forecast.

$$
\widehat{f s i}{ }_{t+j \mid t}^{R}=f s i_{t},
$$

where $f s i_{t}$ is the current value of the financial stress index.

In addition to the RW model, we also employ the following stationary AR (1) model as an alternative benchmark model.

$$
f s i_{t+j}=\alpha_{j} f s i_{t}+\varepsilon_{t+j},
$$

where $\alpha_{j}$ is the coefficient on the current FSTI in the direct regression for the $j$-period ahead FSTI variable, which yields the following $j$-period ahead forecast.

$$
\widehat{f s i_{t+j \mid t}^{A R}}=\hat{\alpha}_{j} f s i_{t},
$$

For evaluations of the prediction accuracy of our models, we use the ratio of the root mean squared prediction error (RRMSPE), that is, RMSPE from the benchmark model divided by RMSPE from the factor model. Note that our factor model performs better than the benchmark model when RRMSPE is

2) ADF test results are available upon request. 
greater than 1 .

Also, we employ the Diebold-Mariano-West (DMW) test for further statistical evaluations of our models. For the $D M W$ test, we define the following function.

$$
d_{t}=L\left(\varepsilon_{t+j \mid t}^{A}\right)-L\left(\varepsilon_{t+j \mid t}^{F}\right)
$$

where $\mathrm{L}(\cdot)$ is a loss function from forecast errors under each model, that is,

$$
\varepsilon_{t+j \mid t}^{A}=f s i_{t+j}-\widehat{f s i_{t+j \mid t}^{A}}(A=R W, A R), \quad \varepsilon_{t+j \mid t}^{F}=f s i_{t+j}-\widehat{f s i_{t+j \mid t}^{F}}
$$

One may use either the squared error loss function, $\left(\varepsilon_{t+j \mid t}^{j}\right)^{2}$, or the absolute loss function, $\left|\varepsilon_{t+j \mid t}^{j}\right|$.

The $D M W$ statistic to test the null of equal predictive accuracy, $H_{0}: E d_{t}=0$, is given as follows.

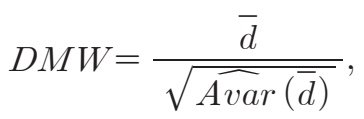

where $\bar{d}$ is the sample mean loss differential, $\bar{d}=\frac{1}{T-T_{0}} \Sigma_{t=T_{0+1}}^{T} d_{t}$, and $\widehat{\operatorname{Avar}}(\bar{d})$ denotes the asymptotic variance of $\bar{d}$,

$$
\widehat{\operatorname{Avar}}(\bar{d})=\frac{1}{T-T_{0}} \sum_{i=-q}^{q} k(i, q) \hat{\boldsymbol{\Gamma}}_{i}
$$

$k(\cdot)$ is a kernel function where $T_{0} / T$ is the split point in percent, $k(\cdot)=0, j>q$, and $\hat{\Gamma}_{j}$ is $j^{\text {th }}$ autocovariance function estimate. ${ }^{3)}$ Note that our factor model (5) nests the stationary benchmark model in (9) with $\beta_{j}=0$. Therefore, we use critical values proposed by McCracken (2007) that re-center the distribution of the test statistic for this case. For the $D M W$ statistic with the random walk benchmark (7), which is not nested by (5), we use the asymptotic critical values, which are obtained from the standard normal distribution.

3) Following Andrews and Monahan (1992), we use the quadratic spectral kernel with automatic bandwidth selection for our analysis. 


\section{Data Descriptions and Factor Estimations}

\subsection{Data descriptions}

We use the financial stress index (FSTI) data to assess the vulnerability in financial sectors in Korea. Financial stress or the vulnerability in financial markets to a financial crisis may be measured by the level of uncertainty in the financial market and/or expected financial losses that could be incurred to financial intermediaries in the economy. Early Warning Indicators (EWI) and Financial Condition Indices (FCI) share similar information as FSTIs in the sense that they all measure the current financial conditions in the economy, though the purposes of those indices are somewhat different.4)

Earlier attempts to develop FSTIs were done by the Bank of Canada in 2003 and the Swiss National Bank in 2004, while the Kansas City Fed and the St. Louis Fed in the U.S. also started using FSTIs since 2008. In Korea, the Bank of Korea developed FSTIs in 2007 and started to report the indices on a yearly basis in their Financial Stability Report. We estimated monthly frequency FSTI data based on the Bank of Korea. Korea's FSTI data is based on 4 sub-indices for the bond market (FSTI-Bond), financial stability report the foreign exchange market (FSTI-FX), the stock market (FSTI-Stock), and the financial industry (FSTI-Industry). Index ranges from 0 to 100 and it reaches to 100 when financial stress is at peak, such as Asian Financial Crisis in 1997.

Each sub-index is constructed as follows. The FSTI-Bond is based on an array of credit spreads, long-short interest rate spreads, and covered interest rate differentials (CID). The FSTI-FX is obtained utilizing the volatility and the growth rate of the Korean Won-U.S. Dollar exchange rate as well as the growth rate of Korea's foreign exchange reserves. The FSTI-Stock is constructed based on the volatility and the growth rate of KOSPI (Korea Composite Stock Price Index), and the volatility and growth rate of the KOSPI trade volume. Lastly, the FSTI-Industry

4) For example, most EWIs are designed to predict the occurence of a financial crisis using qualitative response model framework such as the probit model. FCIs focus more on how financial variables react to changes in the market conditions. 
Figure 1: Financial Stress Index (Dashed) and 4 Sub-Indices

FSTI Bond

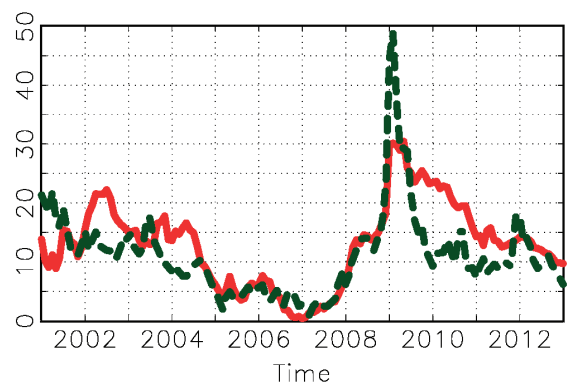

FSTI Stock

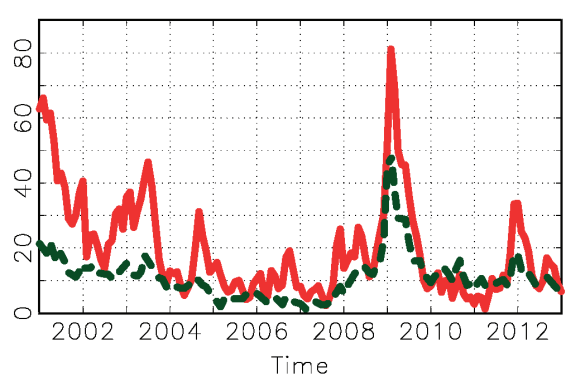

FSTI FX

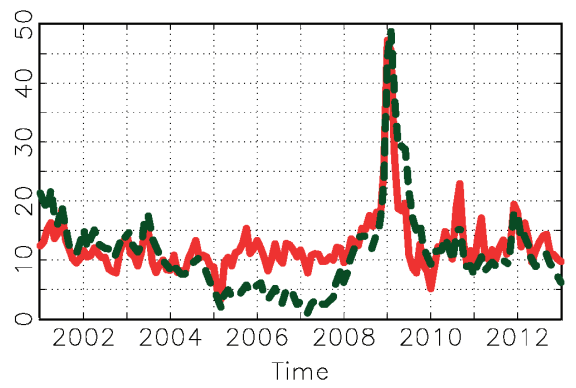

FSTI Industry

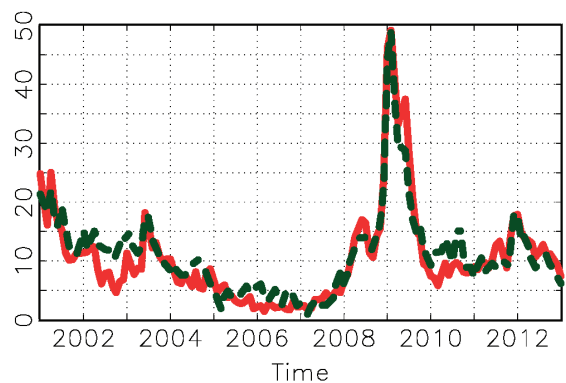

is based on the volatility and the betas of financial intermediaries' stocks, and the spread between the average bond yields issued by financial intermediaries and the treasury bond yield.

As we can see in Figure 1, all sub-indices show overall similar movements as the FSTI total index. FSTI-Bond exhibits much lower volatility than FSTI, while FSTI-Stock shows the highest volatility. All indices imply extremely high degree vulnerability during the recent financial crisis that began in 2008.

We obtained all necessary macroeconomic time series data from Kim (2013), which are used to extract latent common factors for our out-of-sample forecast exercise. Observations are monthly frequency and span from October 2000 to December 2013. We categorized 198 time series data into 13 groups as summarized in Table 1.

Group \# 1 that includes 14 time series data represents a set of nominal interest 


\section{Table 1: Macroeconomic Data Descriptions}

\begin{tabular}{c|c|l} 
Group ID & Data ID & \multicolumn{1}{|c}{ Data Descriptions } \\
$\# 1$ & $1-14$ & Domestic and World Interest Rates \\
$\# 2$ & $15-35$ & Exports / Imports Prices \\
$\# 3$ & $36-54$ & Producer / Consumer / Housing Prices \\
$\# 4$ & $55-71$ & Monetary Aggregates \\
$\# 5$ & $72-83$ & Bilateral Exchange Rates \\
$\# 6$ & $84-110$ & Manufacturers' / Construction New Orders \\
$\# 7$ & $111-117$ & Manufacturers' Inventory Indices \\
$\# 8$ & $118-136$ & Housing Inventories \\
$\# 9$ & $136-157$ & Sales and Capacity Utilizations \\
$\# 10$ & $158-171$ & Unemployment / Employment / Labor Force Participation \\
$\# 11$ & $172-180$ & Industrial Production Indices \\
$\# 12$ & $181-186$ & Business Condition Indices \\
$\# 13$ & $187-198$ & Stock Indices \\
\hline
\end{tabular}

rates. Groups \#2 through \#4 include prices and monetary aggregate variables, while group \#5 covers an array of bilateral nominal exchange rates. Note that these groups overall represent the nominal sector variables. On the contrary, group \#6 through \#11 entail various kinds of real activity variables such as manufacturers' new orders, inventory, capacity utilizations, and industrial production indices. The last two groups represent business condition indices and stock indices in Korea, respectively.

\subsection{Latent factors and their characteristics}

We estimated up to 8 latent common factors by applying the method of the principal compo-nents to 198 macroeconomic data series after differencing and normalizing them. Estimated (differenced) common factors, $\Delta F_{1}, \Delta F_{2}, \cdots \Delta F_{8}$, are reported in Figure 2. We also report level common factors $F_{1}$ through $F_{8}$ in Figure 3 that are obtained by re-integrating differenced common factors.

We first note a dramatic decline in the first common factor $F_{1}$ around the beginning of the Great Recession in 2008. Similarly, the second common factor $F_{2}$ exhibits an abrupt down-ward movement about the same time. All estimated 
Figure 2: Factor Estimates: Differenced Factors

$\Delta F 1$

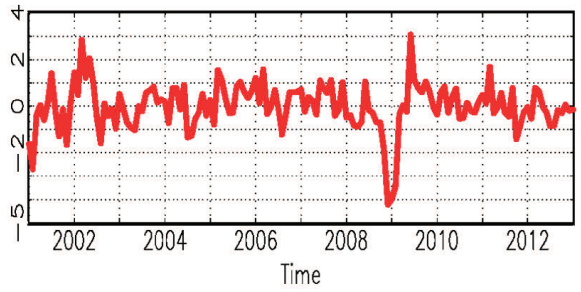

$\Delta F 3$

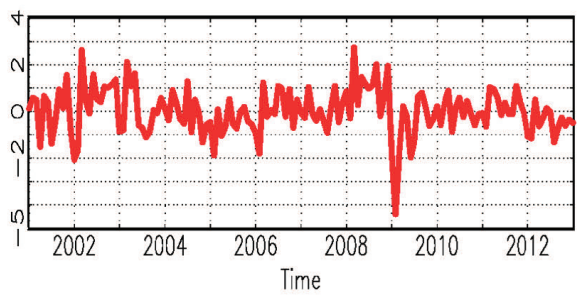

$\Delta F 5$

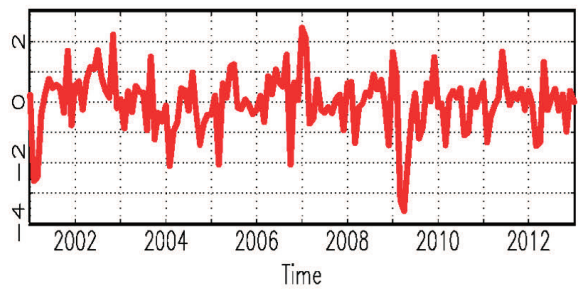

$\triangle F 7$

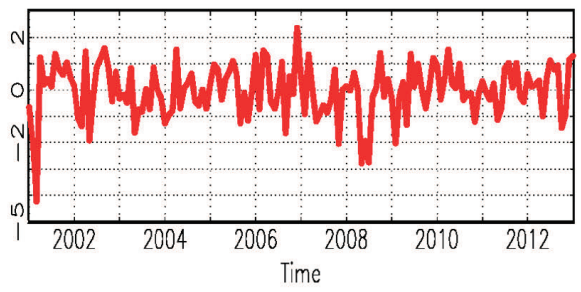

$\Delta F 2$

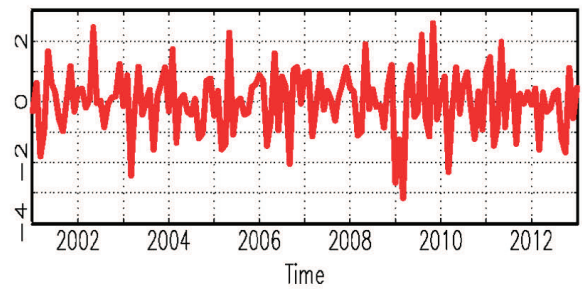

$\triangle F 4$

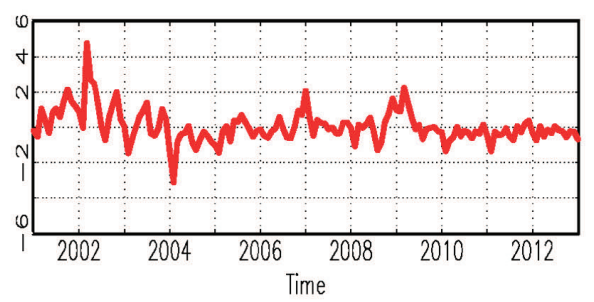

$\triangle F 6$

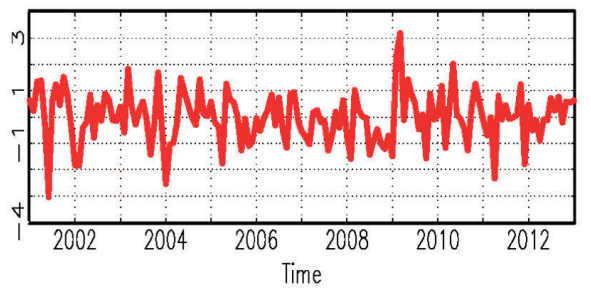

$\triangle F 8$

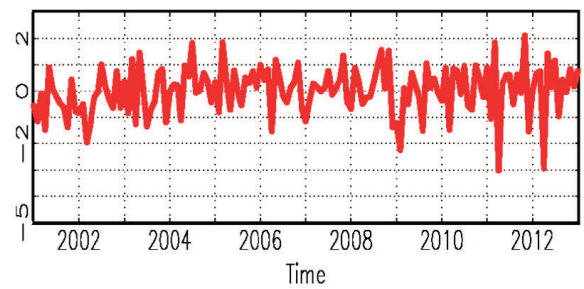

common factors in levels exhibit highly persistent dynamics, indicating nonstationary stochastic processes. Therefore, it seems to be appropriate to employ the method of the principal components to the data after differencing 
Figure 3: Factor Estimates: Level Factors

$\mathrm{F} 1$

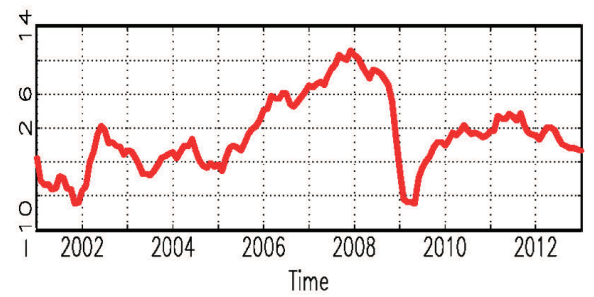

F3

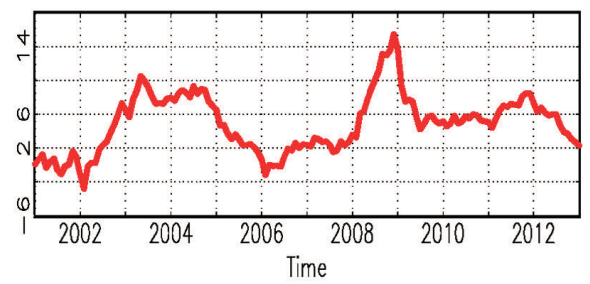

F5

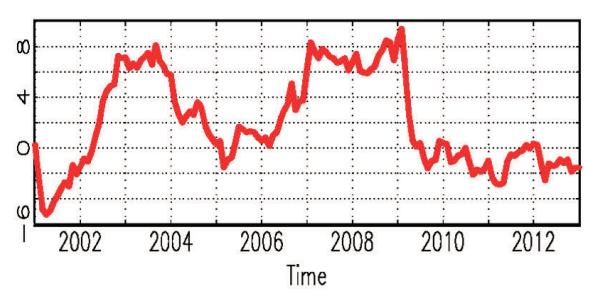

F7

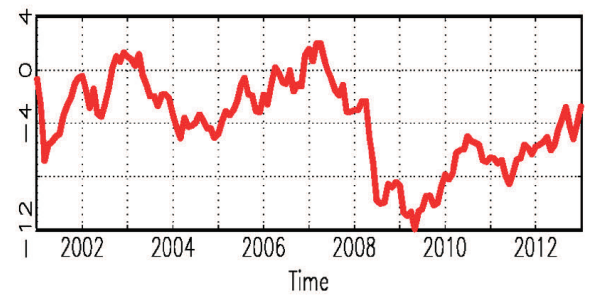

F2

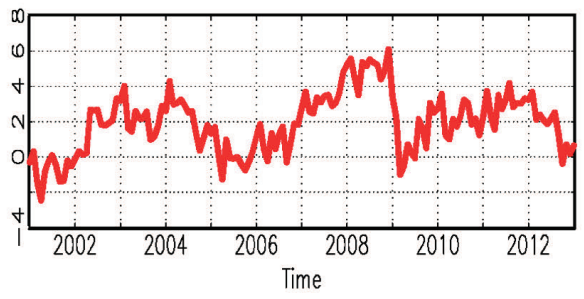

F4

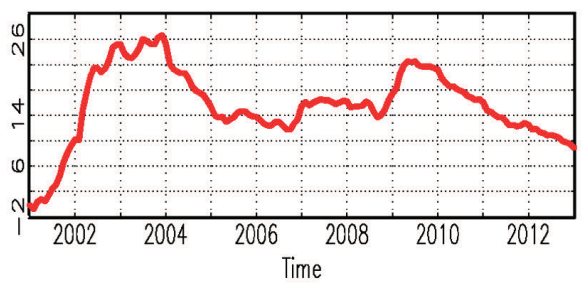

F6

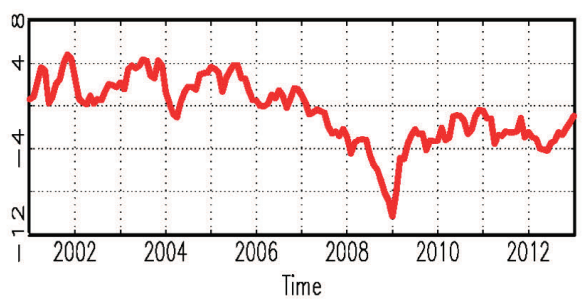

F8

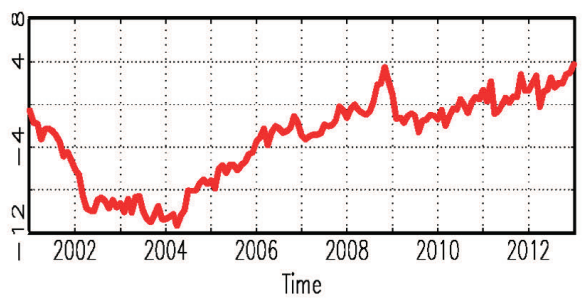

them to ensure the stationarity of the data.

To see what variables represent each of these latent factors more closely, we report the factor loading coefficient $\left(\lambda_{i}\right)$ estimates in Figure 4. We also provide the 
Figure 4: Factor Loading Coefficients Estimates

$\Delta \mathrm{F} 1$

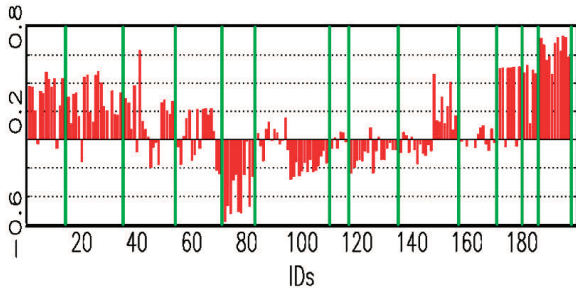

$\Delta \mathrm{F3}$

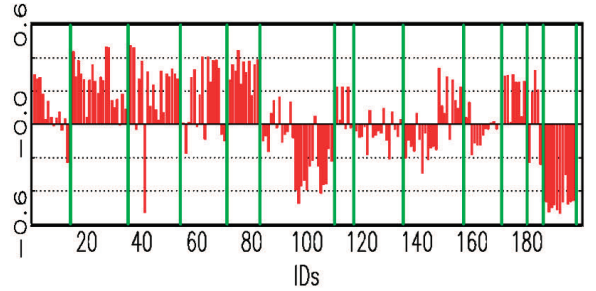

$\Delta F 5$

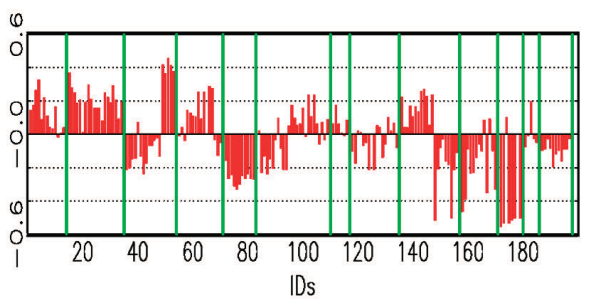

$\Delta F 7$

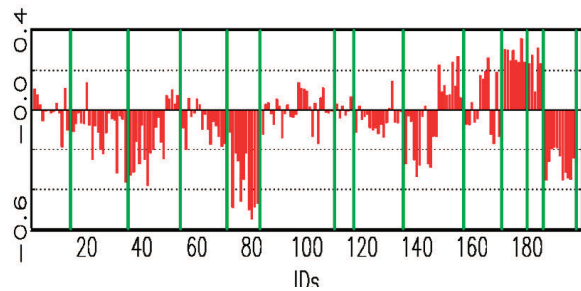

$\Delta F 2$

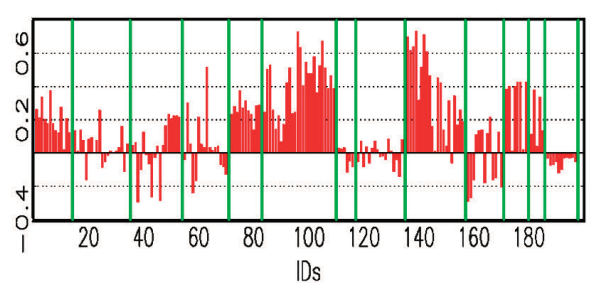

$\triangle F 4$

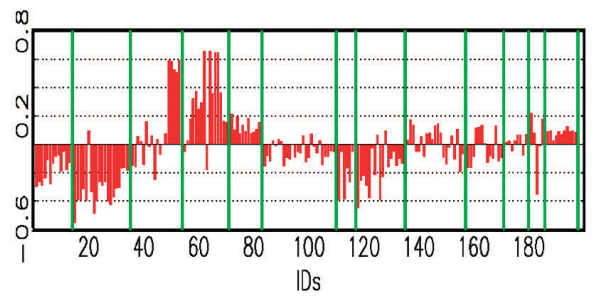

$\triangle F 6$

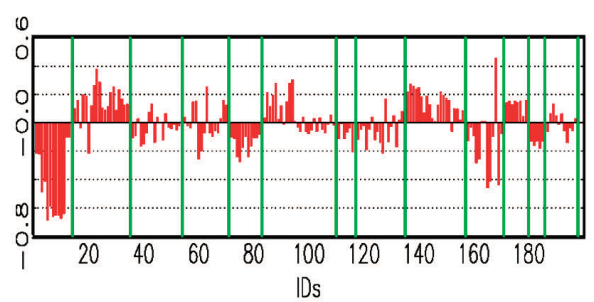

$\triangle F 8$

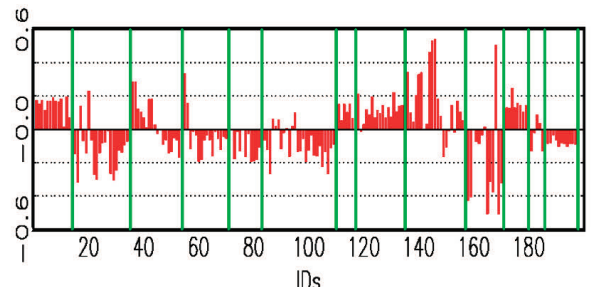

marginal $R^{2}$ analysis by regressing each variable $x_{i, t}$ on each common factor $\Delta \hat{F}_{i}$ to get $R^{2}$ values. Results are reported in Figure 5 .

To investigate the nature of the first common factor, we plot $F_{1}$ and its 
Figure 5: Marginal $R^{2}$ Analysis

$\Delta F 1$
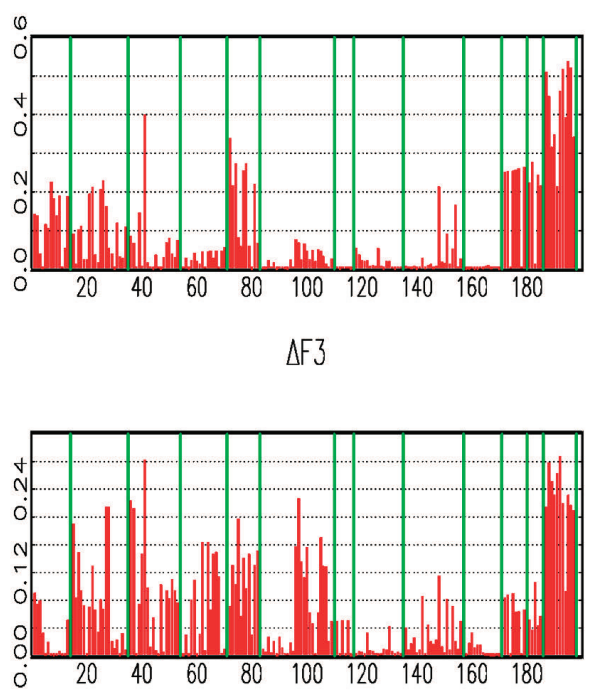

$\Delta F 5$

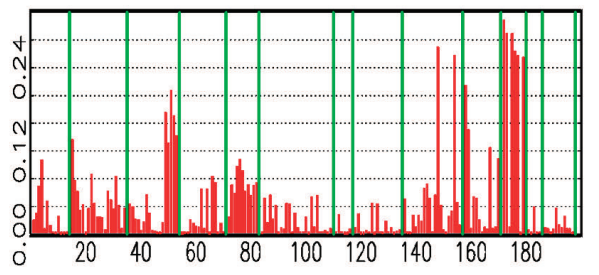

$\triangle F 7$

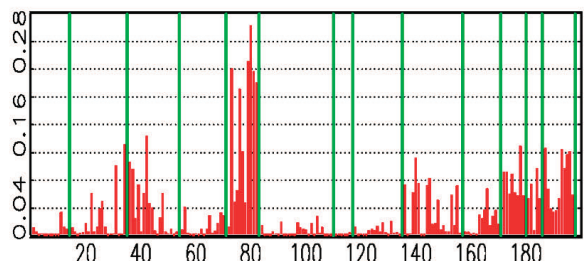

$\Delta F 2$
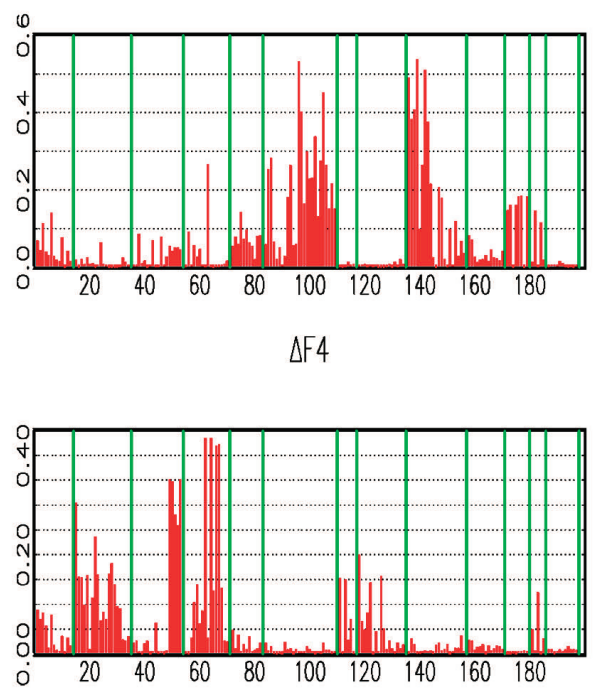

$\Delta F 6$

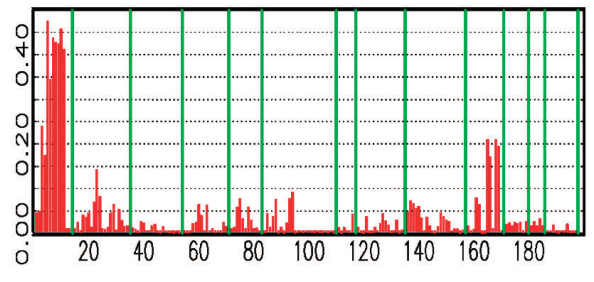

$\Delta F 8$

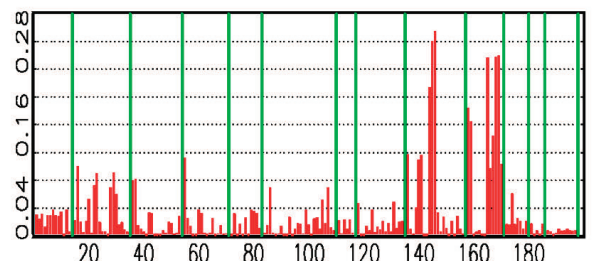

associated factor loading coefficients $\left(\lambda_{i, 1}\right)$ together in Figure 6 . We first note that the factor loading coefficients for the first four groups and the last three groups are dependent upon $F_{1}$ in a positive way, whereas groups \#5, \#6, and \#8 are 
Figure 6: Common Factor \#1 and its Factor Loading Coefficients

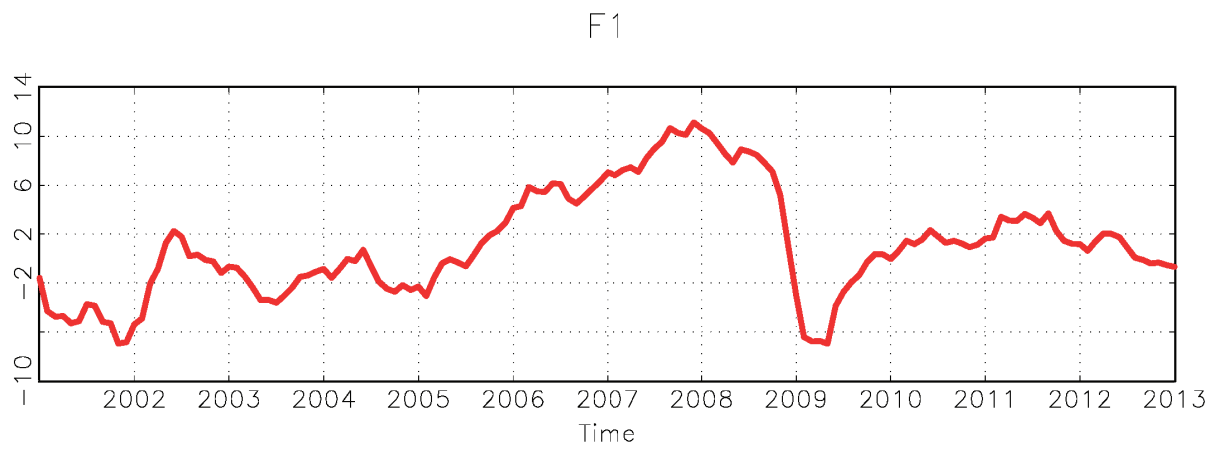

$\triangle F 1$

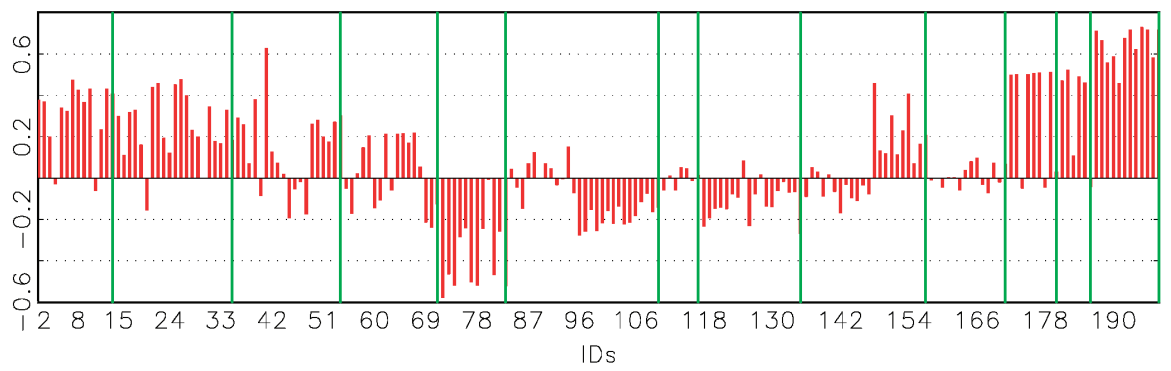

substantially but negatively associated with it. These observations imply that $F_{1}$ represents both the nominal variables (interest rates, prices, nominal exchange rates, and stock prices) and real activity variables (new orders, industrial production, and business condition indices). Factor loading coefficients imply positive associations between Interest rates and prices (inflation rates), which seems to be consistent with the Fisher effect. Domestic prices are negatively related with nominal exchange rates (relative prices of the domestic currency), which also seem plausible.

As we can see in Figure 7, the second common factor seems to closely represent groups \#5, \#6, and \#9 through \#12, which are real sector variables with an exception of group \#5. $F_{2}$ is overall positively related with the majority of the variables in these groups. For instance, the factor loading coefficients $\left(\lambda_{i, 2}\right)$ for nominal exchange rates (group \#5) are positive, which implies that a depreciation 
Figure 7: Common Factor \#2 and its Factor Loading Coefficients

F2

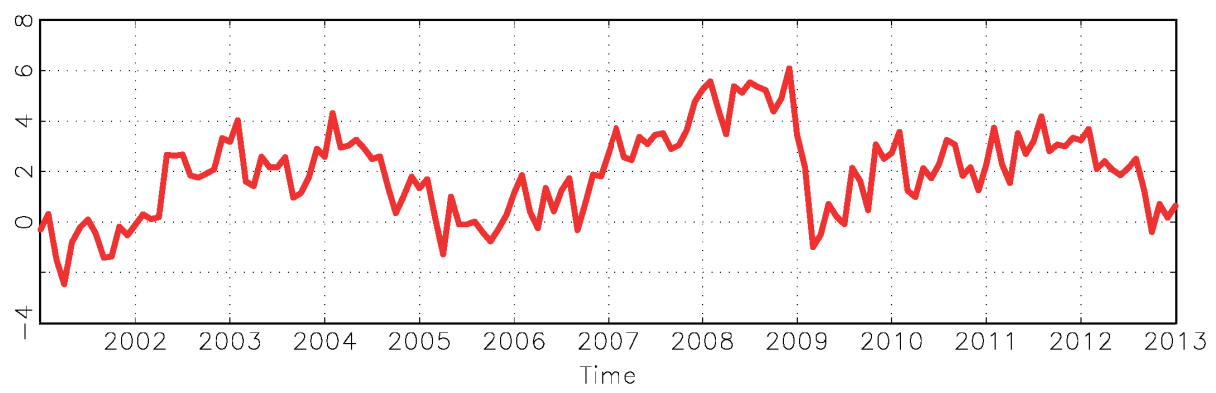

$\triangle F 2$

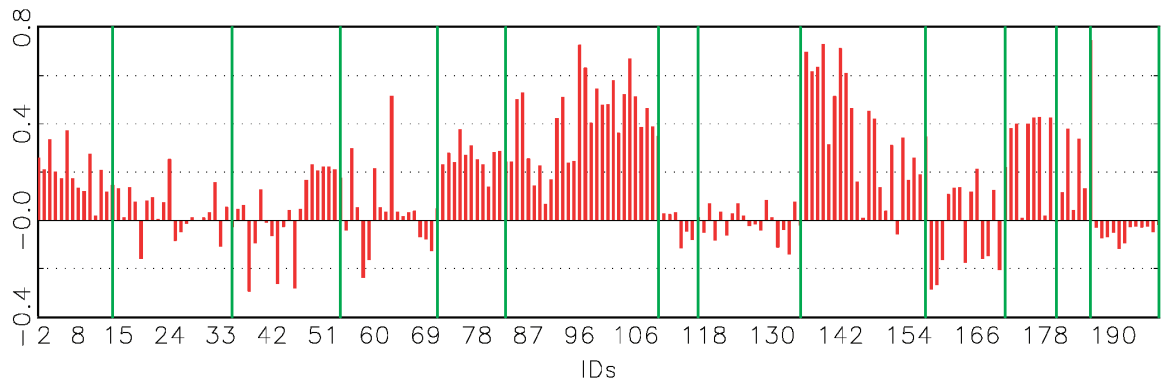

of Korean wons $\left(\Delta x_{i, t}>0\right)$ are associated with an increase in real activities $\left(\Delta F_{2}>0\right)$ in Korea, $\lambda_{i, 2} \Delta F_{2}>0$. Similarly, new orders, sales, industrial production, and business condition indices groups have positive coefficients. Among the group \#10, unemployment variables have negative coefficients, while employment variables tend to exhibit positive ones. Overall, $F_{2}$ seems to represent real sector variables.

In what follows, our in-sample-fit analysis demonstrates a non-negligible role of the fourth common factor $F_{4}$ in explaining FSTIs. 


\section{Forecasting Exercises}

\subsection{In-Sample fit analysis}

We implement an array of least squares estimations for the following equation, employing alternative combinations of estimated common factors $\left\{\Delta \hat{F}_{1}, \Delta \hat{F}_{2}, \cdots, \Delta \hat{F}_{8}\right\}$ as explanatory variables.

$$
f s i_{t+j}=\beta_{j}^{\prime} \Delta \hat{\mathbf{F}}_{t}+u_{t+j}, \quad j=0,1,2, \cdots, k
$$

We report our in-sample fit analyses in Table 2 for the contemporaneous case $(j=0) .5)$

We employed an $R^{2}$-based selection method for one-factor models to an 8 -factor full model to find the best combination of explanatory variables. The first common factor $\Delta \hat{F}_{1}$ seems to play the most important role in explaining variations in all financial stress indices with an exception of FSTI-Bond. The second common factor $\Delta \hat{F}_{2}$ explains negligibly small portion of variations in FSTI. Overall, one or two factor models seem to be sufficient to obtain a good in-sample fit for each financial stress index.

Since $R^{2}$ increases as more variables are included, this $R^{2}$-based selection method always pick the full model as the best one. So, we considered two alternative selection methods. The adjusted $R^{2}$ selection method chose a 7-factor model, while a step-wise selection method (Specific-to-General rule) selected a 6-factor model for FSTI. For FSTI-FX, whereas a 5-factor model was chosen by these two methods. It turns out, however, that fairly small models such as 1 through 3-factor models are good enough to perform well in out-of-sample forecast exercises as will be shown in the next section.

5) Regressions for the 1-, 3-, and 6-month ahead FSTI yield similar results. 
Table 2: In-Sample Fit Analysis for Selection of Factors

Financial Stress Index

\begin{tabular}{|c|c|c|}
\hline \#Factors & Factors & $R^{2}$ \\
\hline 1 & $\Delta \mathrm{F} 1$ & 0.233 \\
\hline 2 & $\Delta \mathrm{F} 1, \Delta \mathrm{F} 4$ & 0.331 \\
\hline 3 & $\Delta \mathrm{F} 1, \Delta \mathrm{F} 4 \quad \Delta \mathrm{F} 5$ & 0.365 \\
\hline 4 & $\Delta \mathrm{F} 1, \Delta \mathrm{F} 4 \Delta \mathrm{F} 5, \Delta \mathrm{F} 8$ & 0.388 \\
\hline 5 & $\Delta \mathrm{F} 1, \Delta \mathrm{F} 4, \Delta \mathrm{F} 5, \Delta \mathrm{F} 7, \Delta \mathrm{F} 8$ & 0.409 \\
\hline $6^{\dagger}$ & $\Delta \mathrm{F} 1, \Delta \mathrm{F} 2, \Delta \mathrm{F} 4, \Delta \mathrm{F} 5, \Delta \mathrm{F} 7, \Delta \mathrm{F} 8$ & 0.421 \\
\hline $7^{*}$ & $\Delta \mathrm{F} 1, \Delta \mathrm{F} 2, \Delta \mathrm{F} 3, \Delta \mathrm{F} 4, \Delta \mathrm{F} 5, \Delta \mathrm{F} 7, \Delta \mathrm{F} 8$ & 0.426 \\
\hline 8 & $\Delta \mathrm{F} 1, \Delta \mathrm{F} 2, \Delta \mathrm{F} 3, \Delta \mathrm{F} 4, \Delta \mathrm{F} 5, \Delta \mathrm{F} 6, \Delta \mathrm{F} 7, \Delta \mathrm{F} 8$ & 0.429 \\
\hline
\end{tabular}

Financial Stress Index: Bond

\begin{tabular}{|c|c|c|}
\hline \#Factors & Factors & $R^{2}$ \\
\hline 1 & $\Delta \mathrm{F} 4$ & 0.036 \\
\hline 2 & $\Delta \mathrm{F} 4, \Delta \mathrm{F} 5$ & 0.054 \\
\hline $3^{\dagger}$ & $\Delta \mathrm{F} 1, \Delta \mathrm{F} 4, \Delta \mathrm{F} 5$ & 0.068 \\
\hline $4^{*}$ & $\Delta \mathrm{F} 1, \Delta \mathrm{F} 4, \Delta \mathrm{F} 5, \Delta \mathrm{F} 8$ & 0.079 \\
\hline 5 & $\Delta \mathrm{F} 1, \Delta \mathrm{F} 2, \Delta \mathrm{F} 4, \Delta \mathrm{F} 5, \Delta \mathrm{F} 8$ & 0.083 \\
\hline 6 & $\Delta \mathrm{F} 1, \Delta \mathrm{F} 2, \Delta \mathrm{F} 4, \Delta \mathrm{F} 5, \Delta \mathrm{F} 6, \Delta \mathrm{F} 8$ & 0.084 \\
\hline 7 & $\Delta \mathrm{F} 1, \Delta \mathrm{F} 2, \Delta \mathrm{F} 3, \Delta \mathrm{F} 4, \Delta \mathrm{F} 5, \Delta \mathrm{F} 6, \Delta \mathrm{F} 8$ & 0.085 \\
\hline 8 & $\Delta \mathrm{F} 1, \Delta \mathrm{F} 2, \Delta \mathrm{F} 3, \Delta \mathrm{F} 4, \Delta \mathrm{F} 5, \Delta \mathrm{F} 6, \Delta \mathrm{F} 7, \Delta \mathrm{F} 8$ & 0.085 \\
\hline
\end{tabular}

Financial Stress Index: Foreign Exchange

\begin{tabular}{|c|c|c|}
\hline \#Factors & Factors & $R^{2}$ \\
\hline 1 & $\Delta \mathrm{F} 1$ & 0.324 \\
\hline 2 & $\Delta \mathrm{F} 1, \Delta \mathrm{F} 4$ & 0.373 \\
\hline 3 & $\Delta \mathrm{F} 1, \Delta \mathrm{F} 4, \Delta \mathrm{F} 7$ & 0.395 \\
\hline 4 & $\Delta \mathrm{F} 1, \Delta \mathrm{F} 4, \Delta \mathrm{F} 6, \Delta \mathrm{F} 7$ & 0.405 \\
\hline $5^{* \dagger}$ & $\Delta \mathrm{F} 1, \Delta \mathrm{F} 4, \Delta \mathrm{F} 5, \Delta \mathrm{F} 6, \Delta \mathrm{F} 7$ & 0.414 \\
\hline 6 & $\Delta \mathrm{F} 1, \Delta \mathrm{F} 2, \Delta \mathrm{F} 4, \Delta \mathrm{F} 5, \Delta \mathrm{F} 6, \Delta \mathrm{F} 7$ & 0.417 \\
\hline 7 & $\Delta \mathrm{F} 1, \Delta \mathrm{F} 2, \Delta \mathrm{F} 4, \Delta \mathrm{F} 5, \Delta \mathrm{F} 6, \Delta \mathrm{F} 7, \Delta \mathrm{F} 8$ & 0.419 \\
\hline 8 & $\Delta \mathrm{F} 1, \Delta \mathrm{F} 2, \Delta \mathrm{F} 3, \Delta \mathrm{F} 4, \Delta \mathrm{F} 5, \Delta \mathrm{F} 6, \Delta \mathrm{F} 7, \Delta \mathrm{F} 8$ & 0.419 \\
\hline
\end{tabular}

Financial Stress Index: Stock

\begin{tabular}{|c|c|c|}
\hline \#Factors & Factors & $R^{2}$ \\
\hline 1 & $\Delta \mathrm{F} 1$ & 0.235 \\
\hline 2 & $\Delta \mathrm{F} 1, \Delta \mathrm{F} 4$ & 0.357 \\
\hline 3 & $\Delta \mathrm{F} 1, \Delta \mathrm{F} 4, \Delta \mathrm{F} 8$ & 0.388 \\
\hline 4 & $\Delta \mathrm{F} 1, \Delta \mathrm{F} 4, \Delta \mathrm{F} 7, \Delta \mathrm{F} 8$ & 0.417 \\
\hline 5 & $\Delta \mathrm{F} 1, \Delta \mathrm{F} 4, \Delta \mathrm{F} 6, \Delta \mathrm{F} 7, \Delta \mathrm{F} 8$ & 0.438 \\
\hline 6 & $\Delta \mathrm{F} 1, \Delta \mathrm{F} 4, \Delta \mathrm{F} 5, \Delta \mathrm{F} 6, \Delta \mathrm{F} 7, \Delta \mathrm{F} 8$ & 0.456 \\
\hline 7 & $\Delta \mathrm{F} 1, \Delta \mathrm{F} 2, \Delta \mathrm{F} 4, \Delta \mathrm{F} 5, \Delta \mathrm{F} 6, \Delta \mathrm{F} 7, \Delta \mathrm{F} 8$ & 0.471 \\
\hline $8^{* \dagger}$ & $\Delta \mathrm{F} 1, \Delta \mathrm{F} 2, \Delta \mathrm{F} 3, \Delta \mathrm{F} 4, \Delta \mathrm{F} 5, \Delta \mathrm{F} 6, \Delta \mathrm{F} 7, \Delta \mathrm{F} 8$ & 0.479 \\
\hline
\end{tabular}


Table 2: In-Sample Fit Analysis for Selection of Factors

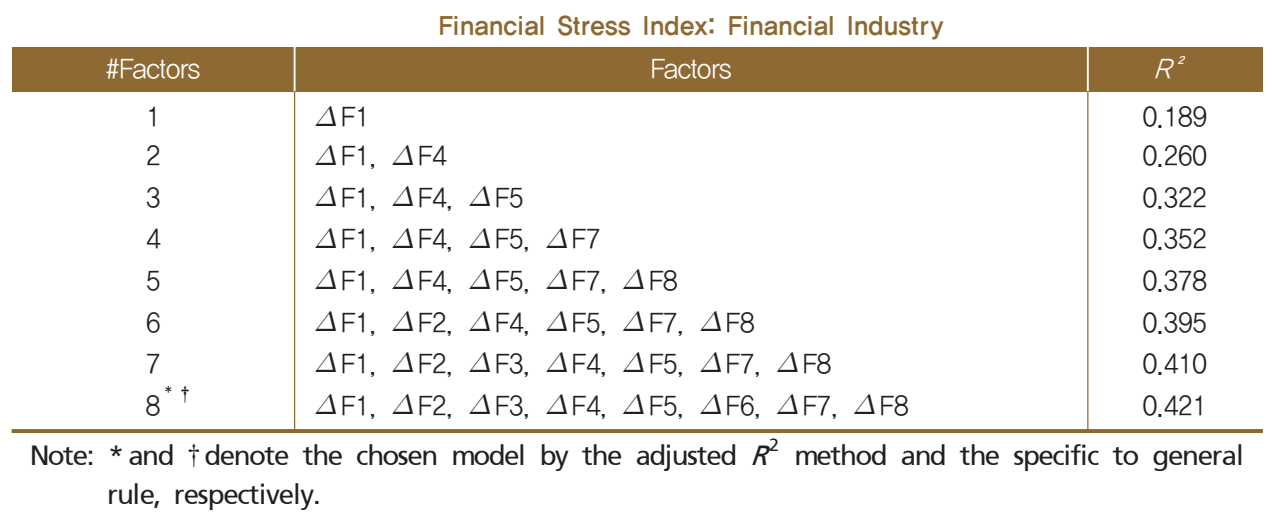

\subsection{Out-of-Sample forecast exercises and model evaluations}

We implement out-of-sample forecast exercise using two methods. We first employ a conventional recursive forecast scheme. That is, we start forecast exercise with an out-of-sample forecast of FSTI using the initial $70 \%$ observations. Then, we add one additional new observation to the sample and implement another forecast of the next index observation using this expanded set of observations. We repeat this procedure until we forecast the last observation. We implement this scheme for up to 12 month forecast horizons, $j=1,3,6,9,12$. The second scheme is a fixed size rolling window method that repeats forecasting by adding one additional observation with the same split point but dropping one earliest observation, maintaining the same sample size, $70 \%$ of total observations.

For statistical evaluations of our factor model, we employ two benchmark models, the random walk (RW, no change) model and a stationary AR (1) model. We evaluate our factor model performances relative to these benchmark models using the following two popular measures.

First, we report the ratio of the root mean square prediction error, RRMSPE, of each of the benchmark models to that of our factor models. Note that the factor model outperforms the benchmark model when the RRMSPE is greater than one. Second, we employ the $D M W$ statistics with asymptotic critical values when the random walk model is used, while the critical values from McCracken (2007) were 
used when the AR model is used because the AR model is nested by our factor models.

Our forecast exercise results for FSTI are reported in Table 3. To save space, we report results with three 1-factor models, two two-factor models, and one three-factor model, which are chosen based on our in-sample fit analyses in previous section.

We first note that our factor models outperform the RW model for all forecast horizons from 1-month to 1-year. RRMSPE is greater than one for all cases. Our factor models outperform the benchmark model with the $D M W$ test for many cases. For example, the $D M W$ test rejects the null of equal predictability at the $10 \%$ significance level for 24 out of 30 cases both with the recursive method and the rolling window method. Especially, we find strong out-of-sample forecast performances when the forecast horizon is equal to or greater than 3 months.

It turns out that our factor models also perform reasonably well in comparison with the stationary AR (1) benchmark model. RRMSPE is greater than one for majority cases when the recursive method is employed, whereas our models perform relatively poorly when the rolling window method is used. Interestingly, the 1-factor model with $\Delta \hat{F}_{4}$, which is more closely related with nominal variables, performs consistently poorly. We note that the $D M W$ test rejects the null of equal predictability for 8 out of 121 -period ahead forecasts, while RRMSPE is greater than one for 10 out of 12 cases. This is a good property because out-of-sample forecast exercises are more useful when it demonstrates superior predictability for short forecast horizon, as financial turmoils often occur suddenly without systematic warnings.

Table 4 reports out-of-sample forecast exercise results for FSTI-Bond. Even though its poor in-sample forecast performances shown in previous section, our factor model beats the RW model again for most cases by RRMSPE criteria. The $D M W$ test rejects the null of equal predictability for most cases when $j=3,6,9$, 12 at the $10 \%$ significance level. With the AR model as the benchmark, our factor models overall perform well especially when $j=3,6,9,12$. Recall that $\Delta \hat{F}_{4}$ explains the most of variations in FSTI-Bond as can be seen in Table 2. We note that $\Delta \hat{F}_{4}$ exhibit the best out-of-sample predictability even when all other models perform poorly in comparison with the AR model. 
Table 3: $j$-Period Ahead Out-of-Sample Forecast: FSTI

\begin{tabular}{|l|c|c|c|c|c}
\multicolumn{7}{|c}{ Recursive Method: RRMSPE vs. Random Walk } \\
\hline \multicolumn{1}{|c|}{ Factors } & $j=1$ & $j=3$ & $j=6$ & $j=9$ & $j=12$ \\
$\Delta \mathrm{F} 1$ & 1.040 & $1.097^{\dagger}$ & $1.251^{\dagger}$ & $1.344^{\dagger}$ & $1.398^{\dagger}$ \\
$\Delta \mathrm{F} 5$ & 1.031 & $1.084^{\dagger}$ & $1.217^{\dagger}$ & $1.296^{\dagger}$ & $1.415^{\dagger}$ \\
$\Delta \mathrm{F} 1, \Delta \mathrm{F} 4$ & $1.049^{\dagger}$ & $1.128^{\dagger}$ & $1.246^{\dagger}$ & $1.331^{\dagger}$ & $1.392^{\dagger}$ \\
$\Delta \mathrm{F} 1, \Delta \mathrm{F} 5$ & 1.039 & $1.076^{*}$ & $1.235^{\dagger}$ & $1.302^{\dagger}$ & $1.416^{\dagger}$ \\
$\Delta \mathrm{F} 1, \Delta \mathrm{F} 4, \Delta \mathrm{F} 5$ & 1.049 & $1.100^{*}$ & $1.279^{\dagger}$ & $1.357^{\dagger}$ & $1.397^{\dagger}$ \\
\hline
\end{tabular}

Rolling Window Method: RRMSPE vs. Random Walk

\begin{tabular}{|c|c|c|c|c|c}
\multicolumn{1}{|c|}{ Factors } & $j=1$ & $j=3$ & $j=6$ & $j=9$ & $j=12$ \\
$\Delta \mathrm{F} 1$ & 1.050 & $1.106^{\dagger}$ & $1.280^{\dagger}$ & $1.378^{\dagger}$ & $1.438^{\dagger}$ \\
$\Delta \mathrm{F} 4$ & 1.021 & $1.085^{*}$ & $1.219^{\dagger}$ & $1.354^{\dagger}$ & $1.432^{\dagger}$ \\
$\Delta \mathrm{F} 5$ & $1.039^{*}$ & $1.111^{\dagger}$ & $1.279^{\dagger}$ & $1.348^{\dagger}$ & $1.442^{\dagger}$ \\
$\Delta \mathrm{F} 1, \Delta \mathrm{F} 4$ & 1.036 & $1.084^{\dagger}$ & $1.244^{\dagger}$ & $1.371^{\dagger}$ & $1.437^{\dagger}$ \\
$\Delta \mathrm{F} 1, \Delta \mathrm{F} 5$ & 1.057 & $1.090^{*}$ & $1.331^{\dagger}$ & $1.374^{\dagger}$ & $1.437^{\dagger}$ \\
$\Delta \mathrm{F} 1, \Delta \mathrm{F} 4, \Delta \mathrm{F} 5$ & 1.043 & 1.071 & $1.295^{\dagger}$ & $1.377^{\dagger}$ & $1.435^{\dagger}$ \\
\hline
\end{tabular}

Recursive Method: RRMSPE vs. Autoregressive

\begin{tabular}{|l|l|l|l|l|l}
\multicolumn{1}{|c|}{ Factors } & $j=1$ & $j=3$ & $j=6$ & $j=9$ & $j=12$ \\
$\Delta \mathrm{F} 1$ & 1.008 & 0.975 & $1.015^{\dagger}$ & $1.014^{\dagger}$ & 1.003 \\
$\Delta \mathrm{F} 4$ & 0.999 & 0.963 & 0.987 & 0.977 & $1.015^{\dagger}$ \\
$\Delta \mathrm{F} 5$ & $1.017^{\dagger}$ & 1.003 & 1.010 & 1.004 & 0.999 \\
$\Delta \mathrm{F} 1, \Delta \mathrm{F} 4$ & 1.007 & 0.956 & 1.001 & 0.982 & $1.016^{\dagger}$ \\
$\Delta \mathrm{F} 1, \Delta \mathrm{F} 5$ & $1.017^{*}$ & 0.977 & $1.037^{\dagger}$ & $1.023^{\dagger}$ & 1.002 \\
$\Delta \mathrm{F} 1, \Delta \mathrm{F} 4, \Delta \mathrm{F} 5$ & $1.015^{*}$ & 0.959 & $1.030^{\dagger}$ & 0.992 & $1.014^{\dagger}$ \\
\hline
\end{tabular}

Rolling Window Method: RRMSPE vs. Autoregressive

\begin{tabular}{|c|c|c|c|c|c}
\multicolumn{1}{|c|}{ Factors } & $j=1$ & $j=3$ & $j=6$ & $j=9$ & $j=12$ \\
$\Delta \mathrm{F} 1$ & $1.020^{*}$ & 0.981 & $1.028^{\dagger}$ & $1.015^{\dagger}$ & 0.998 \\
$\Delta \mathrm{F} 4$ & $0.992^{*}$ & 0.962 & 0.979 & 0.997 & 0.994 \\
$\Delta \mathrm{F} 5$ & $1.009^{\dagger}$ & 0.986 & $1.027^{\dagger}$ & 0.993 & 1.001 \\
$\Delta \mathrm{F} 1, \Delta \mathrm{F} 4$ & $1.007^{*}$ & 0.962 & 0.999 & $1.009^{*}$ & 0.998 \\
$\Delta \mathrm{F} 1, \Delta \mathrm{F} 5$ & $1.027^{*}$ & 0.967 & $1.069^{\dagger}$ & $1.012^{\dagger}$ & 0.998 \\
$\Delta \mathrm{F} 1, \Delta \mathrm{F} 4, \Delta \mathrm{F} 5$ & 1.013 & $0.950^{\dagger}$ & $1.040^{\dagger}$ & $1.014^{\dagger}$ & 0.997 \\
\hline
\end{tabular}

Note: RRMSPE denotes the mean square error from the random walk model relative to the mean square error from our factor model. Therefore, when RRMSPE is greater than one, our factor models perform better than the benchmark model.

Our factor models perform overall the best for FSTI-FX, especially when the rolling window method is employed. RRMSPE is greater than one for all cases with the random walk benchmark model. The $D M W$ test rejects the null for all 
Table 4: $j$-Period Ahead Out-of-Sample Forecast: FSTI-Bond

\begin{tabular}{|c|c|c|c|c|c|}
\hline Factors & $j=1$ & $j=3$ & $j=6$ & $j=9$ & $j=12$ \\
\hline$\Delta \mathrm{F} 4$ & 1.025 & $1.154^{\ddagger}$ & $1.204^{\dagger}$ & $1.365^{\dagger}$ & $1.547^{\neq}$ \\
\hline$\Delta \mathrm{F} 5$ & 0.998 & $1.084^{\dagger}$ & $1.154^{\dagger}$ & $1.243^{\dagger}$ & $1.392^{*}$ \\
\hline$\Delta \mathrm{F} 1$ & 1.000 & 1.047 & $1.141^{\ddagger}$ & $1.239^{\neq}$ & $1.400^{*}$ \\
\hline$\Delta \mathrm{F} 4, \Delta \mathrm{F} 5$ & 1.008 & $1.164^{\dagger}$ & $1.218^{\dagger}$ & $1.375^{\dagger}$ & $1.549^{\ddagger}$ \\
\hline$\Delta \mathrm{F} 4, \Delta \mathrm{F} 1$ & 1.005 & $1.114^{*}$ & $1.207^{\ddagger}$ & $1.368^{*}$ & $1.537^{\ddagger}$ \\
\hline$\Delta \mathrm{F} 1, \Delta \mathrm{F} 4, \Delta \mathrm{F} 5$ & 0.987 & $1.117^{*}$ & $1.218^{\dagger}$ & $1.374^{\dagger}$ & $1.543^{\text {क }}$ \\
\hline
\end{tabular}

\begin{tabular}{|l|c|c|c|c|c}
\multicolumn{7}{|c}{ Rolling Window Method: RRMSPE vs. Random Walk } \\
\multicolumn{1}{|c|}{ Factors } & $j=1$ & $j=3$ & $j=6$ & $j=9$ & $j=12$ \\
$\Delta \mathrm{F} 4$ & 1.033 & $1.158^{\dagger}$ & $1.264^{\dagger}$ & $1.402^{\dagger}$ & $1.639^{\dagger}$ \\
$\Delta \mathrm{F} 5$ & 1.011 & $1.120^{\dagger}$ & $1.257^{\dagger}$ & $1.360^{\dagger}$ & $1.594^{\dagger}$ \\
$\Delta \mathrm{F} 1$ & 1.005 & $1.085^{\dagger}$ & $1.245^{\dagger}$ & $1.335^{\dagger}$ & $1.599^{\dagger}$ \\
$\Delta \mathrm{F} 4, \Delta \mathrm{F} 5$ & 1.021 & $1.170^{\dagger}$ & $1.298^{\dagger}$ & 1.447 & $1.669^{\dagger}$ \\
$\Delta \mathrm{F} 4, \Delta \mathrm{F} 1$ & 1.009 & $1.136^{\dagger}$ & $1.298^{\dagger}$ & $1.437^{\dagger}$ & $1.679^{\dagger}$ \\
$\Delta \mathrm{F} 4, \Delta \mathrm{F} 5, \Delta \mathrm{F} 1$ & 0.998 & $1.142^{\dagger}$ & $1.331^{\dagger}$ & $1.475^{\dagger}$ & $1.697^{\dagger}$ \\
\hline
\end{tabular}

\begin{tabular}{l|l|l|l|l|l}
\multicolumn{7}{c}{ Recursive Method: RRMSPE vs. Autoregressive } \\
\hline \multicolumn{1}{|c|}{ Factors } & $j=1$ & $j=3$ & $j=6$ & $j=9$ & $j=12$ \\
$\Delta \mathrm{F} 4$ & $1.011^{*}$ & $1.076^{\dagger}$ & $1.057^{\dagger}$ & $1.108^{\dagger}$ & $1.116^{\dagger}$ \\
$\Delta \mathrm{F} 5$ & 0.984 & $1.011^{*}$ & $1.013 t$ & $1.009^{\dagger}$ & $1.003^{\dagger}$ \\
$\Delta \mathrm{F} 1$ & 0.986 & 0.976 & 1.002 & 1.006 & 1.009 \\
$\Delta \mathrm{F} 4, \Delta \mathrm{F} 5$ & 0.994 & $1.086^{\dagger}$ & $1.070^{\dagger}$ & $1.116^{\dagger}$ & $1.117^{\dagger}$ \\
$\Delta \mathrm{F} 4, \Delta \mathrm{F} 1$ & 0.990 & $1.039^{\dagger}$ & $1.060^{\dagger}$ & $1.110^{\dagger}$ & $1.108^{\dagger}$ \\
$\Delta \mathrm{F} 4, \Delta \mathrm{F} 5, \Delta \mathrm{F} 1$ & 0.973 & $1.042^{\dagger}$ & $1.069^{\dagger}$ & $1.115^{\dagger}$ & $1.113^{\dagger}$ \\
\hline
\end{tabular}

\begin{tabular}{l|c|c|c|c|c}
\multicolumn{7}{c}{ Rolling Window Method: RRMSPE vs. Autoregressive } \\
\multicolumn{1}{|c|}{ Factors } & $j=1$ & $j=3$ & $j=6$ & $j=9$ & $j=12$ \\
$\Delta \mathrm{F} 4$ & $1.011^{*}$ & $1.050^{\dagger}$ & $1.036^{\dagger}$ & $1.067^{\dagger}$ & $1.052^{\dagger}$ \\
$\Delta \mathrm{F} 5$ & 0.990 & $1.015^{\dagger}$ & $1.031^{\dagger}$ & $1.035^{\dagger}$ & $1.024^{\dagger}$ \\
$\Delta \mathrm{F} 1$ & 0.983 & 0.983 & $1.021^{\dagger}$ & $1.016^{\dagger}$ & $1.027^{\dagger}$ \\
$\Delta \mathrm{F} 4, \Delta \mathrm{F} 5$ & 0.999 & $1.061^{\dagger}$ & $1.064^{\dagger}$ & $1.101^{\dagger}$ & $1.072^{\dagger}$ \\
$\Delta \mathrm{F} 4, \Delta \mathrm{F} 1$ & 0.987 & $1.029^{\dagger}$ & $1.064^{\dagger}$ & $1.094^{\dagger}$ & $1.078^{\dagger}$ \\
$\Delta \mathrm{F} 4, \Delta \mathrm{F} 5, \Delta \mathrm{F} 1$ & 0.976 & $1.035^{\dagger}$ & $1.091^{\dagger}$ & $1.122^{\dagger}$ & $1.090^{\dagger}$ \\
\hline
\end{tabular}

Note: RRMSPE denotes the mean square error from the random walk model relative to the mean square error from our factor model. Therefore, when RRMSPE is greater than one, our factor models perform better than the benchmark model.

cases when the rolling window scheme is employed. Our models exhibit very good one-period ahead forecast performances with the AR benchmark whenever $\Delta \hat{F}_{1}$ is used. 
Table 5: $j$-Period Ahead Out-of-Sample Forecast: FSTI-Foreign Exchange

\begin{tabular}{l|c|c|c|c|c}
\multicolumn{7}{c}{ Recursive Method: RRMSPE vs. Random Walk } \\
\multicolumn{1}{|c|}{ Factors } & $j=1$ & $j=3$ & $j=6$ & $j=9$ & $j=12$ \\
$\Delta \mathrm{F} 1$ & 1.120 & 1.293 & $1.372^{\dagger}$ & $1.617^{\dagger}$ & $1.658^{\dagger}$ \\
$\Delta \mathrm{F} 4$ & 1.095 & $1.237^{\dagger}$ & $1.385^{\dagger}$ & $1.584^{\dagger}$ & $1.614^{\dagger}$ \\
$\Delta \mathrm{F} 7$ & 1.088 & $1.359^{\dagger}$ & $1.312^{\dagger}$ & $1.666^{\dagger}$ & $1.623^{\dagger}$ \\
$\Delta \mathrm{F} 1, \Delta \mathrm{F} 4$ & 1.118 & $1.245^{\dagger}$ & $1.426^{\dagger}$ & $1.590^{\dagger}$ & $1.652^{\dagger}$ \\
$\Delta \mathrm{F} 1, \Delta \mathrm{F} 7$ & 1.109 & 1.349 & 1.336 & 1.675 & $1.657^{\dagger}$ \\
$\Delta \mathrm{F} 1, \Delta \mathrm{F} 4, \Delta \mathrm{F} 7$ & 1.107 & $1.299^{\dagger}$ & $1.402^{\dagger}$ & $1.662^{\dagger}$ & $1.651^{\dagger}$ \\
\hline
\end{tabular}

\begin{tabular}{|l|c|c|c|c|c}
\multicolumn{7}{|c}{ Rolling Window Method: RRMSPE vs. Random Walk } & $j=9$ & $j=12$ \\
\hline \multicolumn{1}{|c|}{ Factors } & $j=1$ & $j=3$ & $j=6$ & $j=9$ \\
$\Delta \mathrm{F} 1$ & $1.126^{*}$ & $1.296^{\dagger}$ & $1.392^{\dagger}$ & $1.611^{\dagger}$ & $1.612^{\dagger}$ \\
$\Delta \mathrm{F} 4$ & $1.088^{*}$ & $1.222^{\dagger}$ & $1.372^{\dagger}$ & $1.611^{\dagger}$ & $1.566^{\dagger}$ \\
$\Delta \mathrm{F} 7$ & $1.095^{\dagger}$ & $1.285^{\dagger}$ & $1.305^{\dagger}$ & $1.688^{\dagger}$ & $1.560^{\dagger}$ \\
$\Delta \mathrm{F} 1, \Delta \mathrm{F} 4$ & $1.120^{*}$ & $1.232^{\dagger}$ & $1.395^{\dagger}$ & $1.618^{\dagger}$ & $1.598^{\dagger}$ \\
$\Delta \mathrm{F} 1, \Delta \mathrm{F} 7$ & $1.124^{\dagger}$ & $1.289^{\dagger}$ & $1.337^{\dagger}$ & $1.673^{\dagger}$ & $1.585^{\dagger}$ \\
$\Delta \mathrm{F} 1, \Delta \mathrm{F} 4, \Delta \mathrm{F} 7$ & $1.117^{*}$ & $1.222^{\dagger}$ & $1.377^{\dagger}$ & $1.679^{\dagger}$ & $1.571^{\dagger}$ \\
\hline
\end{tabular}

\begin{tabular}{|l|l|l|l|l|c}
\multicolumn{7}{|c}{ Recursive Method: RRMSPE vs. Autoregressive } \\
\multicolumn{1}{|c|}{ Factors } & $j=1$ & $j=3$ & $j=6$ & $j=9$ & $j=12$ \\
$\Delta \mathrm{F} 1$ & $1.020^{\dagger}$ & 0.994 & $1.028^{\dagger}$ & $1.003^{*}$ & $1.017^{\dagger}$ \\
$\Delta \mathrm{F} 4$ & 0.997 & 0.951 & $1.038^{\dagger}$ & 0.982 & 0.990 \\
$\Delta \mathrm{F} 7$ & 0.991 & $1.044^{\dagger}$ & 0.983 & $1.033^{\dagger}$ & 0.995 \\
$\Delta \mathrm{F} 1, \Delta \mathrm{F} 4$ & $1.018^{\dagger}$ & 0.957 & $1.069^{\dagger}$ & 0.986 & $1.014^{\dagger}$ \\
$\Delta \mathrm{F} 1, \Delta \mathrm{F} 7$ & $1.010^{*}$ & 1.037 & 1.001 & 1.038 & 1.016 \\
$\Delta \mathrm{F} 1, \Delta \mathrm{F} 4, \Delta \mathrm{F} 7$ & $1.008^{*}$ & 0.998 & $1.051^{*}$ & $1.031^{*}$ & $1.013^{\dagger}$ \\
\hline
\end{tabular}

\begin{tabular}{l|c|c|c|c|c}
\multicolumn{7}{|c|}{ Rolling Window Method: RRMSPE vs. Autoregressive } \\
\multicolumn{1}{|c|}{ Factors } & $j=1$ & $j=3$ & $j=6$ & $j=9$ & $j=12$ \\
$\Delta \mathrm{F} 1$ & $1.029^{\dagger}$ & 0.999 & $1.037^{\dagger}$ & 0.992 & $1.014^{\dagger}$ \\
$\Delta \mathrm{F} 4$ & 0.994 & 0.942 & $1.022^{\dagger}$ & 0.992 & 0.985 \\
$\Delta \mathrm{F} 7$ & 1.000 & 0.991 & 0.973 & $1.040^{\dagger}$ & 0.981 \\
$\Delta \mathrm{F} 1, \Delta \mathrm{F} 4$ & $1.023^{\dagger}$ & 0.950 & $1.039^{\dagger}$ & 0.996 & $1.005^{*}$ \\
$\Delta \mathrm{F} 1, \Delta \mathrm{F} 7$ & $1.027^{\dagger}$ & 0.994 & 0.996 & $1.030^{\dagger}$ & 0.997 \\
$\Delta \mathrm{F} 1, \Delta \mathrm{F} 4, \Delta \mathrm{F} 7$ & $1.020^{\dagger}$ & 0.942 & $1.026^{\dagger}$ & $1.034^{\dagger}$ & 0.988 \\
\hline
\end{tabular}

Note: RRMSPE denotes the mean square error from the random walk model relative to the mean square error from our factor model. Therefore, when RRMSPE is greater than one, our factor models perform better than the benchmark model.

Out-of-sample forecast performances for FSTI-Stock shown in Table 6 sharply contrast results in Table 5. RRMSPE is greater than most cases with the RW benchmark but the $D M W$ test rejects the null of equal predictability only when $j=12$, 
Table 6: $j$-Period Ahead Out-of-Sample Forecast: FSTI-Stock

\begin{tabular}{|c|c|c|c|c|c|}
\hline Factors & $j=1$ & $j=3$ & $j=6$ & $j=9$ & $j=12$ \\
\hline$\Delta \mathrm{F} 1$ & 1.016 & 0.999 & 1.062 & 1.090 & $1.238^{\dagger}$ \\
\hline$\Delta \mathrm{F} 4$ & 1.022 & 1.055 & 1.082 & 1.088 & $1.253^{\dagger}$ \\
\hline$\Delta \mathrm{F} 8$ & 1.033 & 1.056 & 1.114 & 1.103 & $1.239^{*}$ \\
\hline$\Delta \mathrm{F} 1, \Delta \mathrm{F} 4$ & 1.028 & 1.000 & 1.063 & 1.075 & $1.261^{\dagger}$ \\
\hline$\Delta \mathrm{F} 1, \Delta \mathrm{F} 8$ & 1.008 & 0.995 & 1.087 & 1.106 & $1.268^{\dagger}$ \\
\hline$\Delta \mathrm{F} 1, \Delta \mathrm{F} 4, \Delta \mathrm{F} 8$ & 1.013 & 0.995 & 1.086 & 1.093 & $1.298^{\dagger}$ \\
\hline \multicolumn{6}{|c|}{ Rolling Window Method: RRMSPE vs. Random Walk } \\
\hline Factors & $j=1$ & $j=3$ & $j=6$ & $j=9$ & $j=12$ \\
\hline$\Delta \mathrm{F} 1$ & 1.051 & 1.022 & 1.070 & 1.104 & $1.300^{\dagger}$ \\
\hline$\Delta \mathrm{F} 4$ & 1.010 & 1.076 & 1.129 & 1.143 & $1.340^{\dagger}$ \\
\hline$\Delta \mathrm{F} 8$ & 1.038 & 1.074 & 1.161 & 1.152 & $1.302^{\dagger}$ \\
\hline$\Delta \mathrm{F} 1, \Delta \mathrm{F} 4$ & 1.035 & 1.020 & 1.076 & 1.096 & $1.324^{\dagger}$ \\
\hline$\Delta \mathrm{F} 1, \Delta \mathrm{F} 8$ & 1.053 & 1.007 & 1.096 & 1.122 & $1.296^{\ddagger}$ \\
\hline$\Delta \mathrm{F} 1, \Delta \mathrm{F} 4, \Delta \mathrm{F} 8$ & 1.036 & 1.004 & 1.105 & 1.122 & $1.330^{\ddagger}$ \\
\hline
\end{tabular}

Recursive Method: RRMSPE vs. Autoregressive

\begin{tabular}{c|l|l|l|l|l}
\multicolumn{1}{c|}{ Factors } & $j=1$ & $j=3$ & $j=6$ & $j=9$ & $j=12$ \\
$\Delta \mathrm{F} 1$ & 1.000 & 0.945 & 0.975 & $1.004^{\dagger}$ & $1.024^{\dagger}$ \\
$\Delta \mathrm{F} 4$ & $1.006^{\dagger}$ & 0.998 & 0.993 & 1.002 & $1.037^{\dagger}$ \\
$\Delta \mathrm{F} 8$ & $1.016^{\dagger}$ & 0.999 & $1.022^{\dagger}$ & $1.016^{*}$ & $1.025^{\dagger}$ \\
$\Delta \mathrm{F} 1, \Delta \mathrm{F} 4$ & 1.011 & 0.945 & 0.975 & 0.991 & $1.043^{\dagger}$ \\
$\Delta \mathrm{F} 1, \Delta \mathrm{F} 8$ & 0.992 & 0.941 & $0.997^{\dagger}$ & $1.019^{\dagger}$ & $1.049^{\dagger}$ \\
$\Delta \mathrm{F} 1, \Delta \mathrm{F} 4, \Delta \mathrm{F} 8$ & 0.997 & 0.941 & 0.996 & $1.007^{*}$ & $1.074^{\dagger}$ \\
\hline
\end{tabular}

\begin{tabular}{l|c|c|c|c|c}
\multicolumn{7}{c}{ Rolling Window Method: RRMSPE vs. Autoregressive } \\
\multicolumn{1}{|c|}{ Factors } & $j=1$ & $j=3$ & $j=6$ & $j=9$ & $j=12$ \\
$\Delta \mathrm{F} 1$ & $1.034^{*}$ & 0.949 & 0.944 & 0.966 & 0.992 \\
$\Delta \mathrm{F} 4$ & 0.993 & 0.999 & 0.996 & 1.001 & $1.023^{\dagger}$ \\
$\Delta \mathrm{F} 8$ & $1.022^{\dagger}$ & 0.997 & $1.024^{\dagger}$ & $1.009^{*}$ & 0.994 \\
$\Delta \mathrm{F} 1, \Delta \mathrm{F} 4$ & $1.018^{*}$ & 0.947 & 0.949 & 0.960 & $1.011^{*}$ \\
$\Delta \mathrm{F} 1, \Delta \mathrm{F} 8$ & $1.036^{\dagger}$ & 0.935 & 0.967 & 0.982 & 0.989 \\
$\Delta \mathrm{F} 1, \Delta \mathrm{F} 4, \Delta \mathrm{F} 8$ & $1.019^{*}$ & 0.933 & 0.975 & 0.983 & $1.015^{\dagger}$ \\
\hline
\end{tabular}

Note: RRMSPE denotes the mean square error from the random walk model relative to the mean square error from our factor model. Therefore, when RRMSPE is greater than one, our factor models perform better than the benchmark model.

which may not be very useful in practice. With the AR model, factor models performed well only in a few cases, though the $D M W$ test rejects the null for 5 out of 6 cases when the rolling window scheme is used for one-period ahead forecasts. 
Table 7: $j$-Period Ahead Out-of-Sample Forecast: FSTI-Financial Industry

\begin{tabular}{l|l|l|l|l|l}
\multicolumn{7}{|c}{ Recursive Method: RRMSPE vs. Random Walk } \\
\multicolumn{1}{|c|}{ Factors } & $j=1$ & $j=3$ & $j=6$ & $j=9$ & $j=12$ \\
$\Delta \mathrm{F} 1$ & 0.961 & 0.992 & 1.117 & $1.246^{\dagger}$ & $1.428^{\dagger}$ \\
$\Delta \mathrm{F} 4$ & 1.027 & $1.123^{\dagger}$ & $1.218^{\dagger}$ & $1.315^{\dagger}$ & $1.405^{\dagger}$ \\
$\Delta \mathrm{F} 5$ & 1.023 & 1.068 & $1.177^{*}$ & $1.267^{\dagger}$ & $1.409^{\dagger}$ \\
$\Delta \mathrm{F} 1, \Delta \mathrm{F} 4$ & 0.946 & 1.015 & $1.172^{*}$ & $1.294^{\dagger}$ & $1.423^{\dagger}$ \\
$\Delta \mathrm{F} 1, \Delta \mathrm{F} 5$ & 0.953 & 0.970 & 1.132 & $1.245^{\dagger}$ & $1.426^{\dagger}$ \\
$\Delta \mathrm{F} 1, \Delta \mathrm{F} 4, \Delta \mathrm{F} 5$ & 0.937 & 0.996 & $1.213^{*}$ & $1.308^{\dagger}$ & $1.423^{\dagger}$ \\
\hline
\end{tabular}

\begin{tabular}{l|c|c|c|c|c}
\multicolumn{7}{c}{ Rolling Window Method: RRMSPE vs. Random Walk } \\
\multicolumn{1}{|c|}{ Factors } & $j=1$ & $j=3$ & $j=6$ & $j=9$ & $j=12$ \\
$\Delta \mathrm{F} 1$ & 0.953 & 0.979 & 1.117 & $1.256^{\dagger}$ & $1.424^{\dagger}$ \\
$\Delta \mathrm{F} 4$ & 1.017 & $1.130^{\dagger}$ & $1.193^{\dagger}$ & $1.386^{\dagger}$ & $1.400^{\dagger}$ \\
$\Delta \mathrm{F} 5$ & 1.024 & 1.044 & $1.217^{\dagger}$ & $1.236^{\dagger}$ & $1.388^{\dagger}$ \\
$\Delta \mathrm{F} 1, \Delta \mathrm{F} 4$ & 0.923 & 0.997 & 1.140 & $1.356^{\dagger}$ & $1.427^{\dagger}$ \\
$\Delta \mathrm{F} 1, \Delta \mathrm{F} 5$ & 0.951 & 0.954 & $1.153^{*}$ & $1.223^{\dagger}$ & $1.407^{\dagger}$ \\
$\Delta \mathrm{F} 1, \Delta \mathrm{F} 4, \Delta \mathrm{F} 5$ & 0.920 & 0.979 & $1.203^{*}$ & $1.350^{\dagger}$ & $1.417^{\dagger}$ \\
\hline
\end{tabular}

\begin{tabular}{|l|c|c|c|c|c}
\multicolumn{7}{|c}{ Recursive Method: RRMSPE vs. Autoregressive } \\
\multicolumn{1}{|c|}{ Factors } & $j=1$ & $j=3$ & $j=6$ & $j=9$ & $j=12$ \\
$\Delta \mathrm{F} 1$ & 0.934 & 0.891 & 0.947 & 0.974 & $1.010^{\dagger}$ \\
$\Delta \mathrm{F} 4$ & 0.998 & 1.007 & $1.032^{\dagger}$ & 1.029 & 0.994 \\
$\Delta \mathrm{F} 5$ & 0.995 & 0.959 & 0.998 & 0.991 & 0.997 \\
$\Delta \mathrm{F} 1, \Delta \mathrm{F} 4$ & 0.920 & 0.911 & 0.993 & 1.012 & $1.007^{\dagger}$ \\
$\Delta \mathrm{F} 1, \Delta \mathrm{F} 5$ & 0.927 & 0.871 & 0.959 & 0.974 & $1.009^{\dagger}$ \\
\hline
\end{tabular}

\begin{tabular}{l|c|c|c|c|c}
\multicolumn{7}{|c}{ Rolling Window Method: RRMSPE vs. Autoregressive } \\
\multicolumn{1}{|c|}{ Factors } & $j=1$ & $j=3$ & $j=6$ & $j=9$ & $j=12$ \\
$\Delta \mathrm{F} 1$ & 0.926 & 0.875 & 0.931 & 0.975 & $1.014^{\dagger}$ \\
$\Delta \mathrm{F} 4$ & 0.988 & $1.009^{*}$ & 0.995 & $1.076^{\dagger}$ & 0.996 \\
$\Delta \mathrm{F} 5$ & 0.995 & 0.932 & $1.015^{*}$ & 0.960 & 0.987 \\
$\Delta \mathrm{F} 1, \Delta \mathrm{F} 5$ & 0.896 & 0.891 & 0.950 & $1.053^{\dagger}$ & $1.015^{\dagger}$ \\
$\Delta \mathrm{F} 1, \Delta \mathrm{F} 4, \Delta \mathrm{F} 5$ & 0.923 & 0.852 & 0.961 & 0.950 & $1.001^{\dagger}$ \\
\hline
\end{tabular}

Note: RRMSPE denotes the mean square error from the random walk model relative to the mean square error from our factor model. Therefore, when RRMSPE is greater than one, our factor models perform better than the benchmark model.

Finally, we report forecast exercise results for FSTI-Industry in Table 7. Our factor models performed better than the random walk model only when the forecast horizon is longer than a half year. RRMSPE was often less than one when 
$j=1,3$. Forecast performances were worse when the AR model serves as the benchmark. Overall, our factor models perform the worst for FSTI-Industry.

\section{Concluding Remarks}

This paper proposes an out-of-sample forecast model for the financial stress index in Korea in a data rich environment. We use the financial stress index and its 4 subindices to measure the vulnerability in financial markets in Korea. We employ a parsimonious method to extract latent common factors from 198 time series macroeconomic variables that include not only nominal but also real activity variables. Following Bai and $\mathrm{Ng}$ (2004), we applied the method of the principal components to these variables after differencing them to estimate the common factors consistently. Our in-sample fit analyses demonstrate that estimated factors explain substantial shares of variations of all financial stress indices with an exception of FSTI-Bond.

We implement out-of-sample forecast exercises using the recursive and the fixed size rolling window schemes with the two benchmark modes, the random walk and a stationary AR (1) models. We evaluate out-of-sample predictability of our factor models using the ratio of root mean square prediction errors (RRMSP $E$ ) and the $D M W$ test statistics. Our findings imply that there exist a tight linkage between the Korean FSTIs and macroeconomic common factors. Interestingly, we observe that not only nominal but also real activity variables, proxied especially by the first common factor estimate, seem to contain useful predictive contents for FSTIs in Korea. Especially, our factor models demonstrate superior performance over the random walk benchmark model in most cases. Our models also show fairly good performances relative to the AR model in short forecast horizons, which can be practically more useful because financial crises often occur abruptly. We also find parsimonious models that are based on a few common factors perform as well as other bigger models. 


\section{References}

Donald W. K. Andrews, and J. Christopher Monahan (1992), “An Improved Heteroskedasticity and Autocorrelation Consistent Covariance Matrix Estimator," Econometrica, Vol. 60(4), pp. 953-966.

Jushan Bai, and Serena Ng (2004), "A Panic Attack on Unit Roots and Cointegration," Econometrica, Vol. 72, pp. 1127-1177.

Andrew Berg, and Catherine Pattillo (1999), "Predicting Currency Crises: The Indicators Approach and an Alternative," Journal of International Money and Finance, Vol. 18(4), pp. 561-586.

Andrew Berg, Eduardo Borensztein, and Catherine Pattillo (2005), "Assessing Early Warning Systems: How Have They Worked in Practice?" IMF Working Paper 04/52, International Monetary Fund.

Axel Brüggemann, and Thomas Linne (1999), "How Good are Leading Indicators for Currency and Banking Crises in Central and Eastern Europe? An Empirical Test," IWH Discussion Papers, No. 95, Halle Institute for Economic Research.

Matthieu Bussiere, and Christian Mulder (1999), "External Vulnerability in Emerging Market Economies - How High Liquidity Can Offset Weak Fundamentals and The Effects of Contagion," IMF Working Papers 99/88.

Emrah Ismail Cevik, Sel Diboogu, and Turalay Kenc (2013), "Measuring Financial Stress in Turkey," Journal of Policy Modeling, Vol. 35, pp. 370-383.

Ian Christensen, and Fuchun Li (2014), "Predicting Financial Stress Events: A Signal Extraction Approach," Working Paper No. 37, Bank of Canada.

Andrea Cipollini, and George Kapetanios (2009), "Forecasting Financial Crises and Contagion in Asia Using Dynamic Factor Analysis," Journal of Empirical Finance, Vol. 16(2), pp. 188-200.

Hali J. Edison (2003), "Do Indicators of Financial Crises Work? An Evaluation of an Early Warning System," International Journal of Finance and Economics, Vol. 8(1), pp. 11-53. 
M. EI-Shagi, T. Knedlik, and G. Von Schweinitz (2013), "Predicting Financial Crises: The (Statistical) Significance of the Signals Approach," Journal of International Money and Finance, Vol. 35, pp. 75-103.

Barry Eichengreen, Andrew K. Rose, and Charles Wyplosz (1995), "Exchange Market Mayhem: The Antecedents and Aftermath of Speculative Attacks," Economic Policy, Vol. 10(21), pp. 249-312.

Jeffrey Frankel, and George Saravelos (2012), "Can Leading Indicators Assess Country Vulnerability? Evidence from the 2008-09 Global Financial Crisis," Journal of International Economics, Vol. 87, pp. 216-231

Jeffrey A. Frankel, and Andrew K. Rose (1996), "Currency Crashes in Emerging Markets: An Empirical Treatment," Journal of International Economics, Vol. 41(3/4), pp. 351-366.

Lance Girton, and Don Roper (1977), "A Monetary Model of Exchange Market Pressure Applied to the Postwar Canadian Experience," American Economic Review, Vol. 67, pp. 537-548.

Marianna B. Grimaldi (2010), "Detecting and Interpreting Financial Stress in the Euro Area," ECB Working Paper Series No. 1214, European Central Bank.

Marianna B. Grimaldi (2011), "Up For Count? Central Bank Words and Financial Stress," Sveriges Riksbank Working Paper Series 252.

Elke Hanschel and Pierre Monnin (2005), "Measuring and Forecasting Stress in the Banking Sector: Evidence from Switzerland," BIS Paper No. 22, Bank for International Settlements.

Jakob L. Hansen (2006), “A Risk Index for Euro-Denominated Assets," National Bank of Denmark Working Paper No. 36.

Daniel Hollo, Manfred Kremer, and Marco Lo Duca (2012), "Ciss-A Composite Indicator of Systemic Stress in the Financial System," ECB Working Paper Series No. 1426.

Mark Illing, and Ying Liu (2006), "Measuring Financial Stress in a Developed Country: An Application to Canada," Journal of Financial Stability, Vol. 2(3), pp. 243-265. 
Mevlud Islami, and Jeong-Rong Kurz-Kim (2013), "A Single Composite Financial Stress Indicator and its Real Impact in the Euro Area," Discussion Paper No. 31, Deutsche Bundesbank.

Graciela Kaminsky, Saul Lizondo, and Carmen Reinhart (1998), "Leading Indicators of Currency Crises," IMF Working Paper No. 45, International Monetary Fund.

Hyeongwoo Kim, and Wen Shi (2015), "Forecasting Financial Market Vulnerability in the U.S.: A Factor Model Approach," Technical Report, Auburn University.

Hyun Hak Kim (2013), "Forecasting Macroeconomic Variables Using Data Dimension Reduction Methods: The Case of Korea," BOK Working Paper No. 26, Bank of Korea.

Dimitrios P. Louzis, and Angelos T. Vouldis (2011), A Financial Systemic Stress Index for Greece. Presented at the First Conference of the Macro-prudential Research (MaRs) Network of the European System of Central Banks in Frankfurtam Main.

Michael W. McCracken (2007), "Asymptotics for Out of Sample Tests of Granger Causality," Journal of Econometrics, Vol. 140, pp. 719-752.

Miroslav Misina, and Greg Tkacz (2009), "Credit, Asset Prices, and Financial Stress," International Journal of Central Banking, Vol. 5, pp. 95-122.

Miguel A. Morales, and Dairo Estrada (2010), "A Financial Stability Index for Colombia," Annals of Finance, Vol. 6(4), pp. 555-581.

Mikhail V. Oet, Ryan Eiben, Timothy Bianco, Dieter Gramlich, and Stephen J. Ong (2011), "The Financial Stress Index: Identification of System Risk Conditions," Working Paper No. 1130, Federal Reserve Bank of Cleveland.

Jeffrey Sachs, Aaron Tornell, and Andres Velasco (1996), "Financial Crises in Emerging Markets: The Lessons from 1995," Brookings Papers on Economic Activity, Vol. 27(1), pp. 147-199.

Johannes Sandahl, Mia Holmfeldt, Anders Rydén, and Maria Strömqvist (2011), "An Index of Financial Stress for Sweden," Sveriges Riksbank Economic Review, Vol. 2, pp. 49-67. 
Jan Willem Slingenberg, and Jakob De Haan (2011), "Forecasting Financial Stress," DNB Working Paper No. 292, De Nederlandsche Bank.

James H. Stock, and Mark W. Watson (2002), "Macroeconomic Forecasting Using Diffusion Indexes," Journal of Business and Economic Statistics, Vol. 20(2), pp. $147-162$.

Matthew S. Yiu, Wai.-Yip Alex Ho, and Lu Jin (2010), “A Measure of Financial Stress in Hong Kong Financial Market: The Financial Stress Index," Hong Kong Monetary Authority Research Note No. 02.

Evan Tanner (2002), "Exchange Market Pressure, Currency Crises, and Monetary Policy: Additional Evidence from Emerging Markets," IMF Working Papers No. $02 / 14$.

Björn Van Roye (2011), "Financial Stress and Economic Activity in Germany and the Euro Area," Kiel Working Paper No. 1743, Kiel Institute for the World Economy. 


\section{<Abstract in Korean>}

\section{금융스트레스지수의 예측: 요인모형을 통한 접근}

\section{김형우* 김현학** Wen Shi***}

금융위기 발생 여부를 예측하기 위한 노력의 일환으로 다수의 중앙은행이 Financial STress Indices (FSTI)*를 작성·발표하고 있으면 한국은행 또한 지난 2007년부터 FSTI*를 전체지수외에도 채권시장, 외환시장, 주식시장, 금융시장 등 시장의 부문별 지수들의 1995 년 시점부터 시작하는 시계열을 발표하고 있다. 이런 FSTI를 보다 정확하게 예측할 수 있으면 이는 금융위기 예측에 도움이 될 수 있으며, 조기경보시스템(Early Warning System) 구축의 기반이 된다. 본고에서는 대량의 거시경제변수로부터 주성성분석을 통해 주요요인들을 찾고 이를 통해 FSTI를 예측하는 방법을 찾고자 하였다. 실증분석 결과 거시변수들의 주요요인이 FSTI에 대해 상당한 예측력을 가지는 것으로 분석되었으며, 특히 실물활동을 반영하는 주요요인들이 FSTI 예측에 매우 유용한 것으로 보인다. $1 \sim 3$ 개의 요인들만 사용한 전망모형이 단기 FSTI전망에서 우수한 것으로 보여 전략적인 간결한(parsimonious) 전망모형이 금융위기 예측에 유용할 것으로 보임

핵심 주제어: 금융스트레스자수, 주성분분석, PANIC, 표본내 적합, 표본외 예측, Diebold-Mariano-West 검정

JEL Classification: C53, G17, C38

\footnotetext{
* Auburn University 경제학과 교수(gmmkim@gmail.com, 1-334-844-2928)

** 한국은행 경제연구원 거시경제연구실 전문연구원(khdouble@bok.or.kr, 02-759-5471)

*** Auburn University 경제학과 박사과정(gmmkim@gmail.com, 1-334-844-2928)

이 연구내용은 집필자의 개인의견이며 한국은행의 공식견해와는 무관합니다. 따라서 본 논문의 내용을 보도 하거나 인용할 경우에는 집필자명을 반드시 명시하여 주시기 바랍니다.
} 


\section{$\mathrm{BOK}$ 경제연구 발간목록}

BOK 경제연구 발간목록은 매년 6-12월 첫 번째 발간호에서 보실 수 있습니다.

\section{제2013 -1 The Operation of Macroprudential Policy Measures: The Case of Korea in the 2000s}

2 Capital Inflow Shocks and House Prices: Aggregate and Regional Evidence from Korea

3 Cash, Checkable Deposits and Cost of Inflation

4 Systemic Liquidity Shortages and Interbank Network Structures

5 신용카드시장의 의무수납제도가 신용카드 수수료체계에 미치는 영향에 대한 연구

6 Copula를 이용한 은행부문의 시스템적 리스크 측정

7 Skill-biased Technological Change in Small Open Economies:

Accounting for Changing Employment and Wage Structures of Korea

8 Agricultural Sector Development and Structural Transformation: Sub-Saharan Africa versus East Asia

9 A Study on Mortgage Loan Borrowing Behavior of Korean Households: A Micro Perspective

10 Central, Traditional and Shadow Banking in the Multiple Deposit Creation Scheme

11 국내 은행의 자금조달 구조와 기업대출
Jong Kyu Lee

Peter Tillmann

Manjong Lee •

Sung Guan Yun

Seung Hwan Lee

윤선중·강경훈·김정규

이긍희 $\cdot$ 이명활 · 이종한

Chul In Lee $\cdot$ Yong Min Kim

Hee-Sik Kim • Mthuli Ncube

Yong Sun Kim •

Kwang Kyu Lim

Byoung-Ki Kim

\section{정호성}

Jack Joo K. Ree .

Kyoungsoo Yoon.

Hail Park 


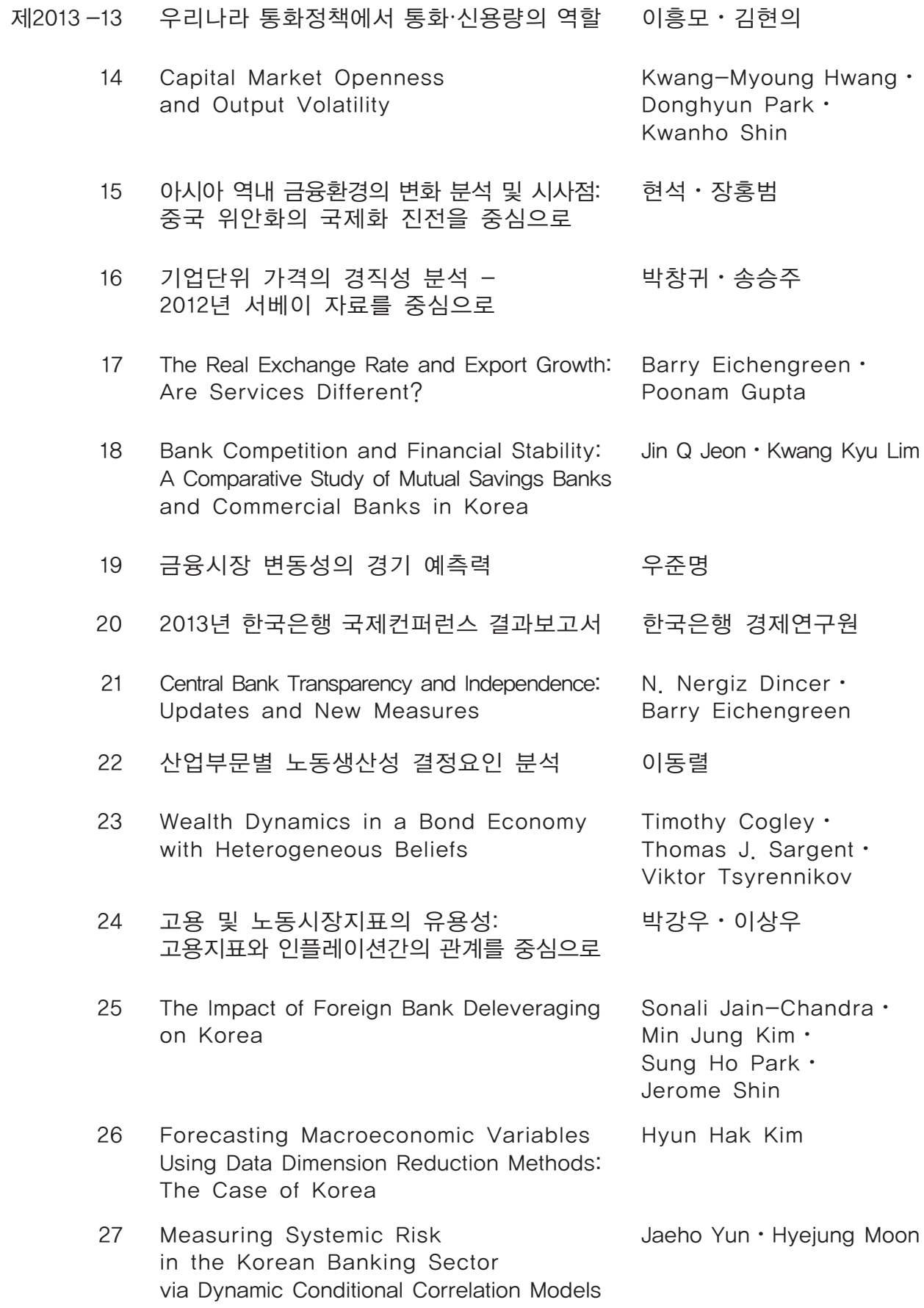

15 아시아 역내 금융환경의 변화 분석 및 시사점: 현석·장홍범 중국 위안화의 국제화 진전을 중심으로

16 기업단위 가격의 경직성 분석 2012년 서베이 자료를 중심으로

박창귀·송승주

17 The Real Exchange Rate and Export Growth: Are Services Different?

Barry Eichengreen •

Poonam Gupta

18 Bank Competition and Financial Stability:

Jin Q Jeon • Kwang Kyu Lim A Comparative Study of Mutual Savings Banks and Commercial Banks in Korea

19 금융시장 변동성의 경기 예측력

우준명

20 2013년 한국은행 국제컨퍼런스 결과보고서

한국은행 경제연구원

21 Central Bank Transparency and Independence: Updates and New Measures

N. Nergiz Dincer • Barry Eichengreen

22 산업부문별 노동생산성 결정요인 분석

이동렬

23 Wealth Dynamics in a Bond Economy

Timothy Cogley • with Heterogeneous Beliefs

Thomas J. Sargent . Viktor Tsyrennikov

24 고용 및 노동시장지표의 유용성: 고용지표와 인플레이션간의 관계를 중심으로

박강우·이상우

25 The Impact of Foreign Bank Deleveraging on Korea

Sonali Jain-Chandra Min Jung Kim. Sung Ho Park • Jerome Shin

26 Forecasting Macroeconomic Variables Hyun Hak Kim Using Data Dimension Reduction Methods: The Case of Korea

27 Measuring Systemic Risk in the Korean Banking Sector Jaeho Yun $\cdot$ Hyejung Moon via Dynamic Conditional Correlation Models 


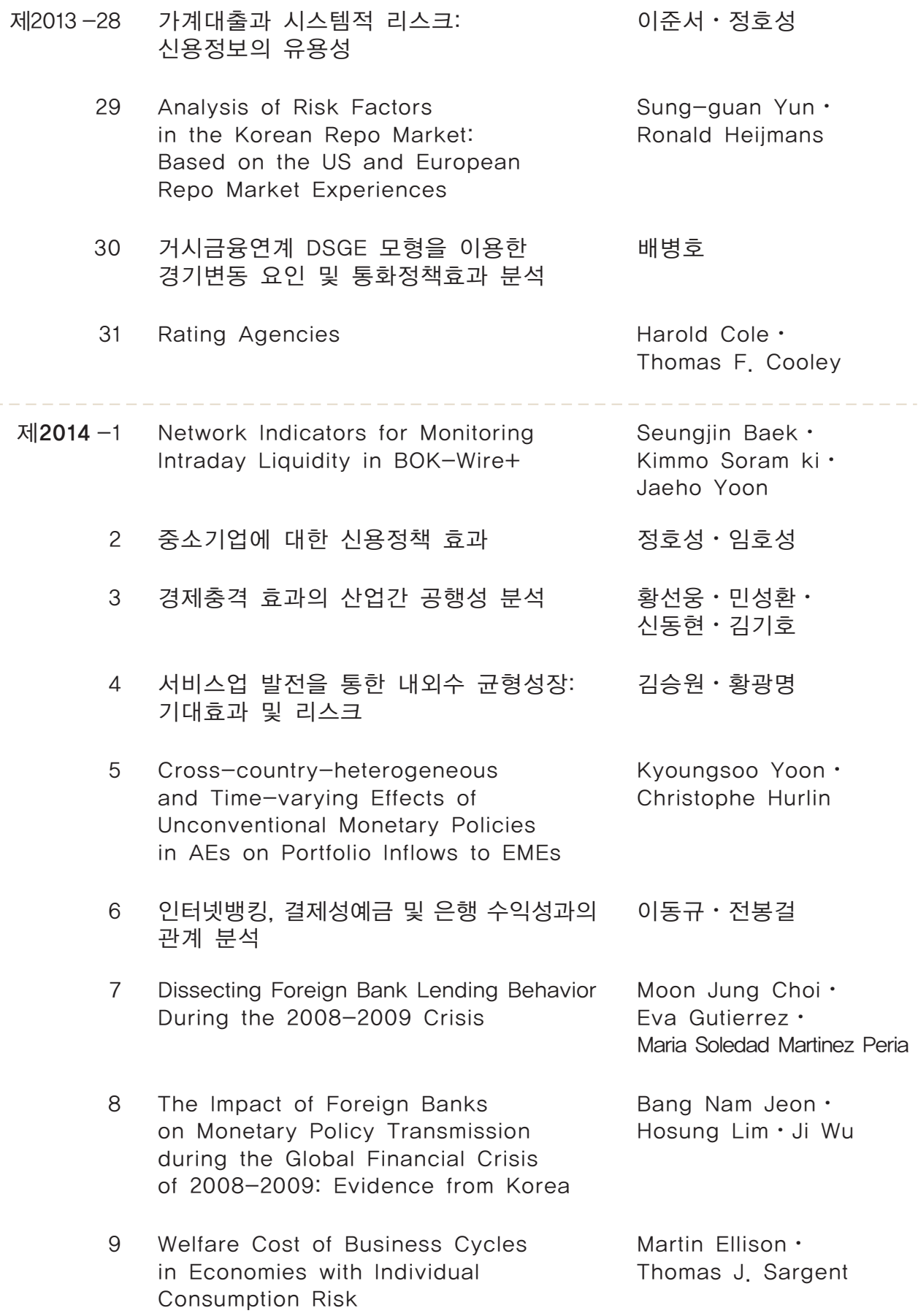

2 중소기업에 대한 신용정책 효과

3 경제충격 효과의 산업간 공행성 분석

4 서비스업 발전을 통한 내외수 균형성장: 김승원 - 황광명 기대효과 및 리스크

5 Cross-country-heterogeneous and Time-varying Effects of Unconventional Monetary Policies in AEs on Portfolio Inflows to EMEs

6 인터넷뱅킹, 결제성예금 및 은행 수익성과의 관계 분석

7 Dissecting Foreign Bank Lending Behavior During the 2008-2009 Crisis

\section{Kyoungsoo Yoon •} Christophe Hurlin

8 The Impact of Foreign Banks on Monetary Policy Transmission during the Global Financial Crisis of 2008-2009: Evidence from Korea

9 Welfare Cost of Business Cycles

Seungjin Baek • Kimmo Soram ki Jaeho Yoon

정호성·임호성

황선웅 - 민성환 ·

신동현 · 김기호

Sung-guan Yun •

Ronald Heijmans

배병호

이준서·정호성

Martin Ellison •

Thomas J. Sargent

Moon Jung Choi •

Eva Gutierrez •

Maria Soledad Martinez Peria

Bang Nam Jeon •

Hosung Lim . Ji Wu 


\begin{tabular}{|c|c|c|}
\hline 제2014 -10 & $\begin{array}{l}\text { Investor Trading Behavior } \\
\text { Around the Time of Geopolitical Risk } \\
\text { Events: Evidence from South Korea }\end{array}$ & $\begin{array}{l}\text { Young Han Kim. } \\
\text { Hosung Jung }\end{array}$ \\
\hline 11 & $\begin{array}{l}\text { Imported-Inputs Channel of } \\
\text { Exchange Rate Pass-Through: Evidence } \\
\text { from Korean Firm-Level Pricing Survey }\end{array}$ & $\begin{array}{l}\text { Jae Bin Ahn } \\
\text { Chang-Gui Park }\end{array}$ \\
\hline 12 & 비대칭 금리기간구조에 대한 실증분석 & 김기호 \\
\hline 13 & $\begin{array}{l}\text { The Effects of Globalization } \\
\text { on Macroeconomic Dynamics } \\
\text { in a Trade-Dependent Economy: } \\
\text { the Case of Korea }\end{array}$ & Fabio Milani $\cdot$ Sung Ho Park \\
\hline 14 & $\begin{array}{l}\text { 국제 포트폴리오투자 행태 분석: 채권-주식 } \\
\text { 투자자금간 상호관계를 중심으로 }\end{array}$ & 이주용·김근영 \\
\hline 15 & $\begin{array}{l}\text { 북한 경제의 추격 성장 가능성과 } \\
\text { 정책 선택 시나리오 }\end{array}$ & 이근·최지영 \\
\hline 16 & $\begin{array}{l}\text { Mapping Korea's International Linkages } \\
\text { using Generalised Connectedness Measures }\end{array}$ & Hail Park $\cdot$ Yongcheol Shin \\
\hline 17 & $\begin{array}{l}\text { 국제자본이동 하에서 환율신축성과 } \\
\text { 경상수지 조정: 국가패널 분석 }\end{array}$ & 김근영 \\
\hline 18 & $\begin{array}{l}\text { 외국인 투자자가 외환시장과 주식시장 간 } \\
\text { 유동성 동행화에 미치는 영향 }\end{array}$ & 김준한 $\cdot$ 이지은 \\
\hline 19 & $\begin{array}{l}\text { Forecasting the Term Structure } \\
\text { of Government Bond Yields } \\
\text { Using Credit Spreads and Structural Breaks }\end{array}$ & $\begin{array}{l}\text { Azamat Abdymomunov } \\
\text { Kyu Ho Kang } \\
\text { Ki Jeong Kim }\end{array}$ \\
\hline 20 & $\begin{array}{l}\text { Impact of Demographic Change } \\
\text { upon the Sustainability of Fiscal Policy }\end{array}$ & $\begin{array}{l}\text { Younggak Kim· } \\
\text { Myoung Chul Kim } \\
\text { Seongyong Im }\end{array}$ \\
\hline 21 & $\begin{array}{l}\text { The Impact of Population Aging } \\
\text { on the Countercyclical Fiscal Stance in Korea, } \\
\text { with a Focus on the Automatic Stabilizer }\end{array}$ & $\begin{array}{l}\text { Tae-Jeong Kim } \cdot \\
\text { Mihye Lee } \cdot \text { Robert Dekle }\end{array}$ \\
\hline 22 & $\begin{array}{l}\text { 미 연준과 유럽중앙은행의 비전통적 통화정책 } \\
\text { 수행원칙에 관한 고찰 }\end{array}$ & 김병기·김진일 \\
\hline 23 & $\begin{array}{l}\text { 우리나라 일반인의 인플레이션 기대 형성 } \\
\text { 행태 분석 }\end{array}$ & 이한규·최진호 \\
\hline
\end{tabular}


제2014-24 Nonlinearity in Nexus between

Working Hours and Productivity

25 Strategies for Reforming Korea's Labor Market to Foster Growth

26 글로벌 금융위기 이후 성장잠재력 확충: 2014 한국은행 국제컨퍼런스 결과보고서

27 인구구조 변화가 경제성장률에 미치는 영향: 자본이동의 역할에 대한 논의를 중심으로

28

Safe Assets

29 확장된 실업지표를 이용한 우리나라 노동시장에서의 이력현상 분석

30

Entropy of Global Financial Linkages

31 International Currencies Past, Present and Future: Two Views from Economic History

32 금융체제 이행 및 통합 사례:

남북한 금융통합에 대한 시사점

33

Measuring Price-Level Uncertainty and Instability in the U.S., 1850-2012

34 고용보호제도가 노동시장 이원화 및 노동생산성에 미치는 영향

35 해외충격시 외화예금의 역할 : 주요 신흥국 신용스프레드에 미치는 영향을 중심으로

Global Liquidity Transmission to Emerging Market Economies, and Their Policy Responses
Dongyeol Lee •

Hyunjoon Lim

Mai Dao · Davide Furceri •

Jisoo Hwang $\cdot$

Meeyeon Kim •

Tae-Jeong Kim

한국은행 경제연구원

손종칠

Robert J. Barro

김현학·황광명

Daeyup Lee

Barry Eichengreen

김병연

Timothy Cogley •

Thomas J. Sargent

김승원

정호성·우준명

김인수 · 이명수

황광명 - 김경민 -

노충식·김미진

Woon Gyu Choi •

Taesu Kang •

Geun-Young Kim •

Byongju Lee 
제2015-1 글로벌 금융위기 이후 주요국

통화정책 운영체계의 변화

2 미국 장기시장금리 변동이 우리나라 금리기간구조에 미치는 영향 분석 및 정책적 시사점

3 직간접 무역연계성을 통한 해외충격의 우리나라 수출입 파급효과 분석

4 통화정책 효과의 지역적 차이

5 수입중간재의 비용효과를 고려한 환율변동과 수출가격 간의 관계

6 중앙은행의 정책금리 발표가 주식시장 유동성에 미치는 영향

7 은행 건전성지표의 변동요인과 거시건전성 규제의 영향

8 Price Discovery and Foreign Participation in The Republic of Korea's Government Bond Futures and Cash Markets

9 규제가 노동생산성에 미치는 영향:

한국의 산업패널 자료를 이용한 실증분석

10 인구 고령화와 정년연장 연구

(세대 간 중첩모형(OLG)을 이용한 정량 분석)

11 예측조합 및 밀도함수에 의한 소비자물가 상승률 전망

12 인플레이션 동학과 통화정책

13 Failure Risk and the Cross-Section of Hedge Fund Returns

14 Global Liquidity and Commodity Prices

15 Foreign Ownership, Legal System and Stock Market Liquidity
김병기·김인수

강규호·오형석

최문정·김근영

김기호

김경민

이지은

강종구

Jaehun Choi · Hosung Lim •

Rogelio Jr. Mercado •

Cyn-Young Park

이동렬·최종일·이종한

홍재화 · 강태수

김현학

우준명

Jung-Min Kim

Hyunju Kang •

Bok-Keun $\mathrm{Yu}$.

Jongmin $\mathrm{Yu}$

Jieun Lee $\cdot$ Kee H. Chung 
바젤II 은행 경기대응완충자본 규제의 기준지표에 대한 연구

23 The Effects of Global Liquidity on Global Imbalances

24 실물경기를 고려한 내재 유동성 측정

25 Deflation and Monetary Policy

26 Macroeconomic Shocks and Dynamics of Labor Markets in Korea

27 Reference Rates and Monetary Policy Effectiveness in Korea An Analysis of Trade Patterns in East Asia and the Effects of the Real Exchange Rate Movements

30 Forecasting Financial Stress Indices in Korea: A Factor Model Approach
서현덕·이정연

강종구·임호성

최지영

Jooyong Jun

Chi-Young Choi •

Joo Yong Lee •

Roisin O'Sullivan

Kyoungsoo Yoon Jayoung Kim

한국은행 경제연구원

Marie-Louise DIIGBENOU-KRE •

Hail Park

우준명·이지은

Barry Eichengreen

Tae Bong Kim •

Hangyu Lee

Heung Soon Jung •

Dong Jin Lee.

Tae Hyo Gwon .

Se Jin Yun

\section{Bongseok Choi • Wooyoung Park. Bok-Keun $\mathrm{Yu}$}

Moon Jung Choi Geun-Young Kim • Joo Yong Lee

Hyeongwoo Kim. Hyun Hak Kim • Wen Shi 